\title{
JESUÍTAS E TUPI: 0 ENCONTRO SACRAMENTAL E RITUAL DOS SÉCULOS XVI-XVII
}

\author{
Adone Agnolin \\ Departamento de História-FFLCH/USP
}

\section{Resumo}

Traduzindo os dogmas doutrinais pós-conciliares para os indígenas americanos, os missionários empreendiam uma tradução de uma tradição religiosa ocidental para uma cultura que não participava dela. Os códigos culturais daquela cultura "estranha" deviam servir para inscrever a tradição religiosa ocidental entre os indígenas. Para fazer isso, a "redução" devia corrigir os excessos (dos costumes) e as ausências (de crenças) dos novos catecúmenos americanos. Os excessos impunham a disciplina, enquanto as ausências reclamavam a doutrina. Nesse percurso, o hibridismo cultural decorrente de uma interpretação ritual do encontro doutrinal e sacramental reescreveu a relação com o sagrado segundo uma nova estrutura, tipicamente colonial.

\section{Pallavras-Chave}

Missões jesuíticas • Tradução • Índios Tupi

\section{Abstract}

In translating post-Trentian dogmas to Amerindian peoples, missionaries sought to translate a Western religious tradition to a culture completely unfamiliar with this doctrine. The cultural codes belonging to that "alien" culture were to serve as a medium for inscribing the Western religious tradition among indigenous peoples. In order to do so, missionaries adopted a "reduction" strategy to correct excesses (in customs) and absences (in beliefs) among the Amerindian neophytes. Excesses demanded discipline, while absences called for doctrine. In this process, the ritual reinterpretation of the doctrinal and sacramental encounter resulted in a form of cultural hybridism, which reformatted relations with the sacred according to a new, typically colonial structure.

\section{Keywords}

Jesuit Missions • Translation • Tupi Indians 


\section{Das Disputas Doutrinais Acerca da Fé... à Fé Enquanto Produto Histórico}

Introduzindo a problemática histórica para servir de base à análise do texto tupi dos catecismos brasileiros, num artigo anterior ${ }^{1}$ propusemos uma primeira contextualização esquemática e geral da catequese: o objetivo inicial era aquele de apontar para os principais fundamentos doutrinais que, na perspectiva revolucionária da revelação cristã, se tornarão de extrema importância para fundamentar a "missão" e a conseqüente e necessária prática da catequese missionária. No decorrer do mesmo artigo, apontamos, portanto, para uma contextualização histórica mais atenta da prática missionário-catequética do século XVI - nas suas profundas peculiaridades frente à nova situação histórica que se determinara na Europa, com a crise aprontada pela Reforma - e à conseqüente reformulação da prática missionária, dentro e fora da Europa. Finalmente, com relação ao mundo indígena americano, na parte final do artigo $^{2}$ apontamos para o fato de que, antes de se configurar como uma "experiência religiosa", a conversão vinha se impondo como aquisição de um idioma capaz, por um lado, de dar voz aos sentidos e aos limites da dominação colonial e, por outro, de replasmá-los dentro da nova situação colonial. Se, de fato, nenhuma tradução é neutra, por outro lado, também, nenhuma tradução é incólume. E é, justamente, em relação à "literatura catequética" que podemos verificar este dois aspectos - isto é, o constituir-se dessa "mão dupla" - que caracterizam o sistema da comunicação (catequética) colonial.

A partir da introdução desses aspectos - anteriormente propostos e que aqui não poderemos retomar a não ser remetendo (quando for estritamente necessário) àquele texto -, neste artigo pretendemos esboçar a continuidade da investigação destacando apenas uma fundamental continuidade nos dois contextos, europeu e americano: se, no caso americano, novas gramáticas e novas semânticas serviram para tornar possível a pragmática interpretativa do sistema colonial sub specie religionis, por outro lado, não podemos deixar de

\footnotetext{
${ }^{1}$ AGNOLIN, Adone. "Jesuítas e Selvagens: o encontro catequético no séc. XVI". In: Revista de História, n. 144, $1^{\circ}$ semestre de 2001, pp. 19-71. Trata-se de um artigo que se propôs enquanto síntese de um primeiro Relatório Científico para FAPESP, São Paulo, Fevereiro de 2001, resultado do começo de uma pesquisa de Pós-Doutorado, desenvolvida junto ao Departamento de História-FFLCH/USP e financiada pela Fapesp.
}

${ }^{2}$ Que leva o subtítulo de Conceitos, palavras e gramáticas, pp. 58-65. 
observar que esta linguagem interpretativa tem uma sua história - anterior a esse encontro colonial específico e interna ao próprio Ocidente - e uma sua projeção sobre outras formas de fazer história, modalidades com as quais o Ocidente entrou em contato nessa época. Com relação a isso devemos levar em consideração que, na perspectiva da catequese, sua gramática, sua semântica e suas modalidades de comunicação estruturam-se a partir de uma dimensão comum (universal) do homem enquanto catecúmeno: isto é, a catequese pretende realizar a revelação cristã "ao longo de um caminho histórico da humanidade que torna os homens catecúmenos, isto é, na realização de um projeto (mistério) de Deus que, ao mesmo tempo, transcende a, e se inscreve na, própria história"³.

Ora, se nossa indagação fosse de caráter teológico, diríamos que a fé transcende a história e que a inscrição do mistério na história se resolveria na missio (o anúncio de Deus, enquanto misterium, e de Cristo, enquanto verbum). Nesse caso, a missão imporia ao homem cristão uma obra de "inculturação na fé", da qual a catequese representaria o instrumento doutrinal privilegiado. Todavia, partindo da perspectiva exatamente oposta - isto é, de uma ótica que, histórica ou antropológica que seja, larga mão das transcendências para abrir-se a uma dimensão horizontal da história do homem -, destacamos como, nos pressupostos de nosso estudo e em contraste com a perspectiva (teológica) anterior:

1) a fé se oferece enquanto produto histórico;

2) a missio constitui-se enquanto uma (peculiar) perspectiva histórica de encontro com o 'outro', culturalmente (isto é, historicamente) distinto;

3) a "inculturação na fé" transforma-se em "inculturação $d a$ fé";

4) e, finalmente, quando a missio se estabelece em bases doutrinais (no interior de uma estrutura cultural compartilhada) a inculturação transforma-se em disputa (doutrinal).

Essa seqüência não se pretende um percurso lógico a priori: é o resultado de um determinado percurso histórico que, principalmente (mas não só), em relação ao período que nos interessa, inverte os resultados que produzem essa relação "lógica". Por conseqüência, do ponto de vista histórico, parte-se antes

${ }^{3}$ Ibidem, p. 22. Ver a respeito toda a parte que leva o subtítulo Apontamentos sobre a catequese, pp. 22-25. 
das disputas doutrinais, para começar a se dar conta de que, além da procura de uma inculturação na fé, realiza-se uma inculturação da fé (de um crer que, de alguma forma, se constituirá como tal) que, através da disputa (e, quando possível, da mediação) com o outro doutrinariamente diferenciado (mas historicamente definido), leva à possibilidade de um (de alguma forma) "encontro" com o outro culturalmente (e historicamente) distinto. O reconhecimento histórico (a consciência) desse percurso leva, finalmente, à possibilidade de entender a fé como produto histórico, oferecendo-se enquanto a base que determina o delinear-se da perspectiva antropológica e da história das religiões. Em suma, parte-se das disputas doutrinais, para se chegar à história das religiões ${ }^{4}$.

\section{Sacramentos Tridentinos e Rituais Sociais}

No caso do encontro ensaiado pela missão jesuítica entre os tupi do Brasil, duas perspectivas parecem tecer e determinar a sua característica peculiar e fundante:

1) a primeira (problemática) enquanto problema fundamental na implementação do processo de catequese (o 'problema' da Crença/Fé): enquanto a "fé" revela-se como uma das problemáticas constantes, abordadas pelos nossos catecismos, constituindo o território fundamental para se realizar a missio jesuítica com seus imperativos catequéticos, o destacar-se da possibilidade ameaçadora da ausência de uma 'crença' ou de uma 'fé' colocava em sério risco o próprio fundamento do empreendimento missionário.

\footnotetext{
${ }^{4} \mathrm{O}$ período histórico que interessa nossa investigação adquire uma importância central em relação a essa problemática que se configura, de fato, profundamente enraizada nas disputas doutrinais. Frente aos novos problemas histórico-culturais do começo da Idade Moderna, essas disputas doutrinais encontram seus instrumentos críticos justamente na Traditio da Patrística cristã. E isso, tanto em relação ao seu constituir-se como fundamento da identidade católica, quanto em relação ao mundo da reforma luterana que, projetando na traditio a luz funesta de uma decadência, pretende, de fato, voltar para uma presumida forma original do Cristianismo: este o sentido próprio da Reforma. Nesse contexto histórico de disputas doutrinais, no que diz respeito ao mundo católico, é na relação entre a assembléia conciliar tridentina e o centralismo romano que assistimos ao determinar-se dos resultados mais significativos para uma nova catequese: aquela pós-tridentina. Nessa, alguns importantes aspectos sacramentais emergem em sua nova configuração doutrinal, estabelecendo um conflito - e, até um certo ponto, uma forma de convivência, de longa duração - com os rituais sociais tradicionais.
} 
2) a segunda (resolutiva) delineia-se, por conseqüência, como uma possível solução do impasse da ação missionária, a “'solução' da Idolatria”: frente aos graves riscos representados pela primeira perspectiva, esta última parecia poder realizar aquela re-fundação das hierarquias de sentido requerida pelos missionários, tanto projetando as categorias religiosas ocidentais nas outras culturas, quanto impondo um sentido à própria ação catequizadora que somente a extensão do conceito de religião (decorrente do renascimento europeu) podia, até certo ponto, permitir ${ }^{5}$. Isso significa que, na América, os jesuítas deviam realizar uma primeira transformação simbólica da idolatria: quando era reconhecida nas práticas indígenas, além e apesar de se constituir como "culto das divindades falsas e mentirosas", ela revelavase, pelo menos, como indício de uma outra forma de crer que confirmava a pertença dos indígenas ao comum gênero humano.

Entre o problema da fé e a solução idolátrica, todavia, queremos destacar, no presente artigo, uma outra problemática da investigação que emerge, em sua nova configuração doutrinal para a época, a partir das resoluções doutrinais tridentinas: trata-se daquela relativa aos aspectos sacramentais. A própria documentação catequética, jesuítica e romana, nos revelou, de fato, nesse começo da Idade Moderna, a emergência de uma profunda revolução em curso entre as novidades doutrinais tridentinas e as velhas tradições sociais européias. E, além do mais, parece-nos que os primeiros fundamentos de uma profunda revolução social - que constituirá as características próprias da Idade Moderna enquanto tal - se encontram, justamente, nessa "revolução sacramental".

Por outro lado, se o esforço peculiar no caso da catequização tupi ia, também, na direção de uma transformação simbólica da idolatria, esse esforço mostrava, nesse específico caso, ter que se renovar continuamente enquanto constante "reinvenção da idolatria" que nunca estava garantida. Isto significa

\footnotetext{
${ }^{5}$ A partir desse pressuposto, a prática quotidiana de aculturação teria feito com que o clichê 'idolatria', sofresse, “... a primeira transformação simbólica: seguramente um signo da distância da fé cristã, mas também indício de um crer 'outro' que confirma na prática e com a prática a pertinência dos indígenas ao comum gênero humano". Dessa forma, a idolatria se teria configurado, portanto, "como universalização do crer [que] é a primeira forma geral de pensamento selvagem produzida pela cultura cristã moderna". GASBARRO, Nicola. "Il linguaggio dell'idolatria: per una storia delle religioni culturalmente soggettiva". In: Studie Materiali di Storia delle Religioni, Roma, vol. 62, n.s. XX, nº 1/2, p. 189-221, 1996. p. 205.
} 
que, por um lado, o problema catequético de encontrar uma 'crença' para fundamentar sua missio levava (quase que necessariamente) o missionário em direção a uma 'solução' idolátrica. Quando, todavia, nos momentos críticos, essa última solução afastava-se do horizonte missionário - isto é, quando parecia não haver mais a possibilidade desse reconhecimento entre determinadas culturas indígenas - tornava-se claramente desesperadora a ação missionária ${ }^{6}$.

Sugerida por nossa própria documentação (antes jesuítico-romana e posteriormente jesuítico-missionária), a nova perspectiva de indagação soma-se à peculiaridade segundo a qual tal revolução sacramental realizou-se em relação e em estrita necessária dependência para com as tradições sociais indígenas. À medida em que se delineava, progressivamente, a fragilidade de uma possível 'solução' idolátrica para fundamentar a missão entre os tupi, parece surgir e afirmar-se uma outra forma e estratégia (paralela, antes, e alternativa, depois) de 'solução' que realize (torne possível), de algum modo, o encontro cultural que devia constituirse como base de um complexo processo transculturativo: o encontro catequético devia realizar-se através de um "encontro de ritualidades" que, com seus autos, solenidades e teatro jesuítico, implementaram o Teatro da Fé .

É somente levando em consideração (isto é, historicizando) as problemáticas religiosas (ocidentais) que podemos tentar entender o processo do encontro catequético com os tupi em suas peculiaridades. Todavia, hoje nos parece evidente que, através de uma atenta análise da nossa documentação em terra de missão, o momento ritualista concentre o transbordamento das problemáticas desse encontro por além dos limites, sempre prontamente (e necessariamente) erguidos pelos missionários, de sua "redução religiosa". Esse momento do "encontro ritualista" coloca em foco a rica produção documental que nos permite, de alguma forma, a possibilidade privilegiada de incursão nas culturas indígenas.

\footnotetext{
${ }^{6}$ Exemplo significativo da percepção missionária do iminente risco/possibilidade de falência da própria missio é a lamentação do Pe. Manuel da Nóbrega, a respeito dos Tupinambá brasileiros, feita em 1556: "Se tiveram rei, podérão se converter, ou se adorárão alguma cousa; mas como não sabem, que cousa é crêr, nem adorar, não podem entender a prégação do Evangelho, pois ella se funda em fazer crêr e adorar a um só Deus, e a este só servir; e como este gentio não adora a cousa alguma, nem crê em nada, tudo o que lhe dizeis se fica em nada". Carta de Pe. Manuel da NÓBREGA (1556-57), In: LEITE, Serafim. Cartas dos Primeiros Jesuítas no Brasil. São Paulo, vols. I-III, 1956-58: carta que se encontra no vol. II, p. 320.
}

${ }^{7}$ Segundo o título do livro de KARNAL, Leandro. Teatro da Fé: representação religiosa no Brasil e no México do século XVI. São Paulo: Hucitec, 1998. 
Levando em consideração a centralidade desse característico encontro, acreditamos que poderemos tentar focalizar, na documentação, os momentos (preciosos) em que a conversão podia (devia, segundo nossos pressupostos) adquirir para os índios um sentido próprio que transbordava, necessariamente, aquele de uma (redutiva) experiência religiosa (ocidental). Neste momento privilegiado do encontro (catequético), a tradução das tradições (da cultura) indígena pode, de fato, nos permitir colher, mesmo que sombriamente, tanto algumas características de suas próprias tradições, quanto a peculiar perspectiva-ritual antes que mitológica? - de sua tradução da tradição "religiosa" ocidental. Todavia, pode-se obter este resultado desde o momento em que conseguimos enfocar com clareza os instrumentos que a tradução (ocidental) afinou, no "trabalho de campo" missionário, para traduzir sua alteridade.

Entre o século XVI e o século XVII, verifica-se uma brusca e característica transformação no que diz respeito ao conceito (ocidental) de fé: da suficiência de uma fé ingênua que se caracterizava como sumária adesão a uma ritualidade que permanecia, substancialmente, incompreensível, passa-se para uma nova e forte exigência que vê a fé perder seu primeiro significado de fiducia para ganhar, de maneira definitiva, aquele de crença. Para responder a essa nova exigência, o Catecismo vem se configurando como o instrumento indispensável para fornecer este minimum de conhecimentos ("coisas a serem acreditadas") e, portanto, se impõe como instrumento para as massas. Esse resultado realizase, historicamente, partindo do pressuposto que, no fundo, é a fé, em si, que caracteriza de forma peculiar a religião cristã: fato que determina, de forma significativa, nosso conceito de religião. Explica-se, assim, a contingência histórica que tornou fundamental, para o cristianismo, a profissão de fé ${ }^{8}$. Esta perspectiva nos mostrará como, por exemplo, não é por acaso que, em 1530, encontramos o configurar-se da profissão de fé como "confissão religiosa", assim como não é sem significado o fato de que o começo da Idade Moderna

\footnotetext{
${ }^{8}$ No que diz respeito à peculiaridade da "profissão de fé cristã", poderá revelar-se de grande utilidade seguir algumas das indicações traçadas pelo trabalho de Sabbatucci, no primeiro capítulo de La prospettiva storico-religiosa que leva, de fato, o título (por enquanto) curioso de fede nella fede (fé na fé). Cf. SABBATUCCI, Dario. La Prospettiva Storico-Religiosa: fede, religione e cultura. Milão, Il Saggiatore, 1990. Cf. o capítulo I: fede nella fede, de p. 5 à p. 18.
} 
leve, também, o nome de "Idade Confissional", justamente com o objetivo de distinguir uma comunidade de crentes de outra'.

Essa problemática é de fundamental importância para entender os resultados mais significativos da nova catequese pós-tridentina e, entre esses, a importância do encontro/choque entre a nova normatização dos sacramentos tridentinos e os antigos rituais sociais, sejam esses europeus ou americanos. Em decorrência desse choque, a "consumação do sagrado", adquiriu uma nova caracterização em relação à dimensão ritualista da fé católica. E antes de destacar-se enquanto fenômeno típico da cultura colonial americana, esse fenômeno caracterizou também o encontro (conflito e interação) entre os dois modelos de catolicismo da Europa: um rural, tradicionalista, oral, ritual, centrado nas redes de parentesco, e outro metropolitano, tridentino, textual, sacramental, centrado na responsabilidade individual ${ }^{10}$.

$\mathrm{Na}$ complexidade dos diferentes contextos, da qual se desprende esse conflito cultural, vale a pena notar como, os elementos de mediação fundamentais - isto é, os elementos através dos quais, de algum modo, se realiza o encontro (acomodamento a longo, longuíssimo prazo) das duas diferentes perspectivas culturais - se constituem, justa e significativamente, ao redor dos rituais e dos sacramentos: elementos cruciais e performáticos da transformação mais significativa da sociedade na Idade Moderna. Mesmo que em sua peculiar característica cultural, parece-nos que uma análoga e imprescindível função mediadora caracterizou os rituais e os sacramentos ${ }^{11}$ no lento, mas inexorável, processo de encontro ensaiado em terra americana entre a perspectiva indígena e aquela jesuítica missionária, típica e emblematicamente pós-tridentina.

\footnotetext{
${ }^{9}$ Trata-se, de fato, do ano em que Carlos V presidiu a dieta de Augusta (Augsburg, na Baviera) a fim de resolver a controversa questão religiosa decorrente do nascimento e da difusão do luteranismo. Nesta ocasião - com a importante contribuição de Melanchton, grande humanista amigo de Lutero - os teólogos luteranos elaboraram sua profissão de fé, apresentada à dieta e nota como a "Confissão de Augusta". Em seguida, adequando-se ao ordenamento eclesial das várias comunidades protestantes nacionais, as Confissões se multiplicaram.

${ }^{10}$ Veja-se, a esse respeito, o exemplo da Irlanda gaélica, proposto no trabalho de PO-CHIA HSIA, Ronnie. The World of Catholic Renewal (1540-1770). Trad. it.: Bolonha, Il Mulino, 2001, pp. 119-20. Onde, por exemplo, às páginas 119-20, destaca como "rituais e sacramentos tornaram-se elementos cruciais" ao redor dos quais construir e administrar o encontro (e a compatibilização) entre os dois modelos do catolicismo europeu.

${ }^{11}$ De fato, uma forma necessariamente ritual de aproximação ao "sagrado".
} 


\section{A Fé e Sua Historicização: instrumentos catequéticos e "apresentação da Fé"}

Os catecismos escritos na América fazem parte de um esforço idêntico produzido no Extremo Oriente, na Índia e nas Filipinas, durante o século XVI. Esta produção tão pouco reconhecida como "literária", deve essa problemática classificação justamente ao fato de que tais catecismos, mesmo dentro de sua diversidade, se caracterizam por sua dimensão instrumental: trata-se de instrumentos impressos ou manuscritos, que deviam servir para a "apresentação da fé".

A utilização instrumental dos textos catequéticos, na ótica propriamente missionária, implicava um afastamento inicial da possibilidade de colher uma ótica indígena diferente, dando por pressuposta uma certa "fé na (eficácia da) fé". Essa pretensa (fideística) missionária e os choques dela decorrentes encontrar-se-ão à base da obra e dos equívocos da catequização que, em princípio, pressupunha dever resolver "simplesmente" os problemas da forma e da língua (tradução) dos textos a serem utilizados. Dois motivos nos impõem de esclarecer esse pressuposto: em primeiro lugar, porque diz respeito a alguns equívocos importantes que, desde a atuação missionária ao longo da história do Cristianismo, acompanham essas abordagens de estudos, influenciando ainda hoje parte importante das ciências históricas e das ciências sociais ${ }^{12}$; em segundo lugar, porque esses equívocos adquiriram uma dimensão peculiar e significativa na nova situação de embate entre Velho e Novo Mundo, sobretudo em relação à problemática da nossa indagação.

Sabbatucci releva como, de fato, a história das religiões tem problematizado os objetos de fé, mas não a própria fé. Isso significa que ela não fez, da própria fé, um problema de ordem histórico. A "fé em alguma coisa" apareceu como o ponto central de cada religião, e sendo que se presume que não exista, nem nunca tenha existido, um povo sem religião, considera-se a fé à maneira de um dado (transcendente) e não de um fato (histórico). O dado seria a exigência humana de crer em entidades (seres ou forças) extra-humanas: não tem im-

\footnotetext{
${ }^{12} \mathrm{Cf}$. a definição emblemática de Nicola Gasbarro que, nesta perspectiva, define esquemática e exemplarmente este percurso: "Única cultura no mundo a inventar-se em termos de civilização e de religião, e a construir a sua história e, sucessivamente, aquela do mundo com uma contínua oscilação entre os dois termos, depois da religião natural e do direito natural, o Ocidente inventa a civilização e a religião enquanto construções culturais, isto é, a antropologia e a história das religiões". GASBARRO, Nicola. "Religione e Civiltà: F. Max Müller e E. B. Tylor”. In: Storia, antropologia e scienze del linguaggio, III, 1988, p. 126.
} 
portância por quais fins, sendo que acerca dos fins não existe acordo e, portanto, estes ficam fora do dado, ou daquilo que se aceita como um dado. Ora, é um fato que a fé por si mesma caracteriza a religião cristã e condiciona o nosso conceito de religião; por isso nós estamos acostumados a conceber a própria religião, qualquer que seja, como um comportamento baseado na fé. Mas do ponto de vista histórico-religioso não é correto falar de religiões de outros ignorando este condicionamento ${ }^{13}$. Com certeza o "fideísmo" cristão tem marcado toda a cultura ocidental; portanto o primeiro passo para uma historicização da fé deveria ter como objetivo a verificação da contingência histórica (e da conseqüente necessidade teórica) que tornou fundamental, para o cristianismo, a profissão de fée ${ }^{14}$.

Ponto de partida para uma interpretação crítica é o fato de que não é uma fé que faz a religião, mas é, eventualmente, uma religião que faz (constrói, inventa mesmo) a fé; tal eventualidade encontra-se inscrita no cristianismo, enquanto religião que incluiu a fé nos próprios atos institucionais. A fé por si mesma, isto é, des-historificada, não faz religião ${ }^{15}$. Ora, em relação a esse problema, torna-se evidente que "crer é um conceito genérico e por nada especificamente religioso: pode-se crer em coisas totalmente profanas" ${ }^{16}$. Eventualmente, o próprio Brelich distingue entre "um crer espontâneo e sem alternativas" e o "crer podendo escolher entre diferentes possibilidades"; porém acrescenta: "ambas estas formas do crer podem ser ou profanas ou religiosas". Nessa perspectiva, os cristãos realizaram-se como tais justamente pelo "crer com alternativa". Determinadas circunstâncias históricas os tinham colocado em frente a uma escolha: para se tornar cristãos deviam escolher sê-lo e dar testemunha da escolha através de uma profissão de fé. Foi assim no começo, quando se tratou de escolher entre duas possibilidades: Jesus era ou não era o messias esperado pelo povo hebraico. Aqueles hebreus que escolheram a primeira alternativa deixaram de ser hebreus e tornaram-se cristãos ${ }^{17}$.

Com Jesus, o reino terrestre de Deus, concebido pelos profetas hebraicos, tornou-se o Reino dos Céus, uma realidade extra-mundana, transcendente,

\footnotetext{
${ }^{13}$ SABBATUCCI, Dario. Op. Cit., p. 5.

${ }^{14}$ Ibidem, pp. 7-8.

${ }^{15}$ Ibidem, pp. 9-10.

${ }^{16}$ BRELICH,Angelo. Introduzione alla Storia delle Religioni. Roma: Ed. dell'Ateneo, 1965, pp. 6-7.

${ }^{17}$ SABBATUCCI, Dario. Op. Cit., p. 10-11.
} 
como o próprio Deus, a existência terrena. Aceitar esta nova perspectiva implicava uma profissão de fé na função messiânica de Jesus, mas comportava, sobretudo, uma escolha entre salvação mundana e salvação ultra-mundana. Decorre disso o fato de que se tinha uma identidade hebraica por nascimento, mas tornavam-se cristãos por eleição, através de um ato de fé. $\mathrm{O}$ ato de fé numa realidade ultra-mundana superava o condicionamento mundano da nacionalidade ou, genericamente, do nascimento. Era suficiente um ato de fé no Reino dos Céus que, além disso, em vida, podia ser somente esperado e não experimentado. De experimentável tinha o Império romano, o único modelo histórico da realidade meta-histórica defrontada pelos cristãos em chave de universalidade, enquanto através dele superava-se o condicionamento étnico através da distribuição da civitas romana às pessoas de qualquer raça ${ }^{18}$. Não era coisa de pouca monta: tornar-se súditos do Reino dos Céus significava subverter idealmente os reinos terrestres; historicamente significou subverter o Império romano, o próprio modelo da universalidade: e contra os "subversivos", súditos do Rei dos Céus, o Império romano procedeu em termos de lei. A subversão tornou-se martírio, isto é, testemunha: uma testemunha constituída, também, em termos de lei, tanto que a fé testemunhada tornou-se lei, por sua vez, quando o Império romano se transformou em Império cristão, um império no qual caía-se na ilegalidade se não "se acreditasse" ou não se acreditasse da justa forma. A alternativa do crer tornava-se perigosa e, de qualquer forma, ilegal ${ }^{19}$.

Nessa direção, como bem analisou Anthony Pagden, a extensão da cristandade continuou, sucessivamente, circunscrita ao território que se considerava ter sido ocupado pelo Império romano. "O orbis terrarum se converteu, assim, através da variação efetuada por Leão o Grande no século V, no 'orbis Christianus', que por sua vez se transformou de imediato no 'Imperium Christianum'. Um século depois, Gregório o Grande o traduziria por 'sancta respublica': uma comunidade dotada da mesma exclusividade simultaneamente aberta que havia caracterizado a 'respublica totius orbis' de Cícero”. Portanto, mesmo que nos termos do direito natural todos os homens, fossem pagãos ou cristãos, tivessem idênticos direitos políticos, "os não cristãos, pagãos que também eram barbari, deviam ser animados para juntar-se à 'congregatio fidelium',

\footnotetext{
${ }^{18}$ Ibidem, pp. 11-12.

${ }^{19}$ Ibidem, p. 12.
} 
da mesma forma em que haviam sido impulsionados os 'bárbaros' a integrarse à civitas romana" ${ }^{20}$. Dessa herança cultural do Império romano ${ }^{21}$, resultou $\mathrm{o}$ instituto da Monarchia Universalis que, com o antigo sonho dos imperadores cristãos, "transformou a ambição pagã de civilizar o mundo no objetivo análogo de converter literalmente todos seus habitantes ao cristianismo. O único sistema legal unificador - o koinos nomos - se converteu, assim, num único sistema de crenças. A enorme influência que teve a noção estóica de lei nas reformulações realizadas pelos Padres da Igreja, de Santo Agostinho a São Tomás, assegurou um alto grau de continuidade teórica entre os impérios pagão e cristão e [juntamente] a convicção [...] de que a conversão não podia alcançar-se de forma plena ou adequada sem uma correspondente transformação política e cultural". ${ }^{22}$ Estruturada e potencializada ao longo de toda a Idade Médiaa ${ }^{23}$, essa Monarchia Universalis encontrou-se investida com os Impérios Ibéricos, pouco antes de seu iminente ocaso, da complexa tarefa de administrar o impacto problemático - e suas consequiências teóricas em relação ao instituto monárquico universal - das descobertas americanas.

Conseqüentemente, a missio "religiosa" não se distinguia daquela "política" e, essas duas perspectivas oferecem-se, conjuntamente e ao mesmo tempo, enquanto fundamento da monarquia universal espanhola. Nas palavras da Historia Ecclesiastica Indiana do franciscano Gerónimo de Mendieta (1525-1604), missionário no México a partir de 1554, resume-se significativamente esse aspecto:

"estou firmemente convencido de que, como os reis católicos [Fernando e Isabel] foram encarregados da missão de extirpar os três esquadrões diabólicos do 'pérfido' judaísmo, do 'falso' maometanismo e da 'cega' idolatria, juntamente com o quarto esquadrão dos heréticos, em direção dos quais a Santa Inquisição é remédio e medicina, assim a seus sucessores foi entregue a função de completar a obra. Como Fernando

\footnotetext{
${ }^{20}$ PAGDEN, Anthony. Lords of all the World: Ideologies of empire in Spain, Britain, and France, 1500-1800. Yale University Press, 1995. Trad. Espanhola. Barcelona: Península, 1997, pp. 38-39.

${ }^{21}$ Que não podemos aqui re-visitar em sua complexidade, mas em relação à qual reenviamos, todavia, para a rica e significativa síntese do primeiro capítulo ( A Herança de Roma) da obra citada de PAGDEN, pp. 23-44.

${ }^{22}$ PAGDEN, Anthony. Op. Cit., p. 45

${ }^{23}$ Veja-se, em relação a esse aspecto, o segundo capítulo da obra de Pagden (Monarchia Universalis), pp. 45-86.
} 
e Isabel limparam a Espanha destas pérfidas seitas, assim seus descendentes levarão a término em todo o mundo a destruição universal destas seitas e a conversão final de todos os povos da terra que voltarão, finalmente, ao seio da Igreja".

Nesse específico contexto histórico, a extensão da universalidade do imperium constituiu-se na paralela imposição de civilizar o mundo, segundo o modelo da civitas romana, e converter seus habitantes, segundo o modelo do cristianismo. E se a cultura (moral) do Império romano encontrava-se fundamentada na pietas - que denotava a lealdade familiar e à comunidade, junto com a estreita observância das leis "religiosas" dessa comunidade -, no novo contexto histórico que impunha a equação de "civilizar e converter" (civilizar para converter), a pietas $^{24}$, que tinha sido causa da fundação do Império romano, transforma-se em 'humanidade', base essencial, mas não suficiente, para tornar o homem cristão. Com esses pressupostos e sob a égide dos impérios ibéricos, os missionários puderam levar (construir) a fé católica nas Américas, na África, na Índia e nas Filipinas onde, diferentemente das missões em China e Japão, evangelização e conquista constituíram-se paralelamente. De qualquer forma, para realizar (converter) o homem enquanto tal, tornava-se fundamental transmitir-lhe a "fé na fé". Desse ponto de vista, se a "religião" (pietas) fazia o homem, a "fé" (fides) produzia o cristão. Trata-se, segundo o nosso ponto de vista, de uma distinção de extrema importância, na medida em que, muitas vezes, os dois termos foram confusamente denotados de forma análoga.

De fato, independentemente dos objetos históricos da fé, aos olhos do bom cristão de hoje, assim como aos olhos missionários de outrora, o "pagão" (ou, melhor, o não-cristão) que, apesar de desviar do "verdadeiro objeto", demonstra aderência à própria fé é, de seu jeito, um virtuoso; e, ao contrário, o ateu, o agnóstico ou o céptico, uma pessoa pouco virtuosa. Neste último caso, o que constitui a "diversidade" é, portanto, a falta da fé: esta é uma indicação do grau de qualificação cultural que o fideísmo assumiu entre nós.

No nível da ciência histórico-religiosa, a fé laica num ser supremo foi objetivada numa noção atribuída, com demasiado desembaraço, às culturas mais primitivas, tornando-as assim mais facilmente recuperáveis à nossa fé. Assim,

\footnotetext{
${ }^{24}$ Que compreendia a prática da virtus, a "humanidade" que se expressava na capacidade de valorizar o bem da comunidade, a utilitas publica, acima da própria conveniência pessoal, a utilitas singulorum.
} 
por exemplo, podemos falar de predisposição (cultural) em inventar um Ser supremo a ser atribuído aos povos primitivos: foi o caso da "descoberta" de Andrew Lang no século XIX e de seu pronto recebimento, a "fé num Ser supremo", na etnologia religiosa. A idéia de Deus representa uma componente fundamental da cultura ocidental: não esquecendo isso, poderíamos dizer que aquele Ser supremo que era atribuído às culturas primitivas era o Deus europeu oportunamente des-historificado ou, de qualquer forma, tirado do contexto histórico cristão. Tratava-se de uma realidade filosófica (não necessariamente teológica) à qual parece que o europeu não possa renunciar sem renunciar a tantos pontos fundamentais da própria cultura: de Platão a Kant. Aconteceu assim que o europeu, mesmo quando rejeitou a fé cristã em nome da livre razão, conservou, contudo, o Deus cristão sem ter consciência que fosse tal, mas supondo tratar-se de uma realidade universal (pré-cristã ou a-cristã), isto é, objeto da pesquisa filosófica e não também histórica. A fé sem história torna-se, assim, uma virtude humana e não faz nenhuma diferença que se fale de "fé num Ser supremo", de "fé nos espíritos da natureza", de "fé num ideal", transferindo num nível de comportamento laico a religiosidade própria do fideísmo. ${ }^{25}$

Levando em consideração esses problemas de caráter histórico, que emergem da perspectiva histórico-religiosa, já se entrevê quanto, além dos problemas de clareza doutrinal, de síntese conceitual e de traduzibilidade lingüística, os instrumentos impressos ou manuscritos que deviam servir para a "apresentação da fé" destinada às novas populações do orbis Christianus determinaram um espaço para um "encontro" que se constituirá necessariamente repleto de equívocos. E serão justamente esses equívocos que se tornarão as peças fundamentais sobre as quais se estrutura a possibilidade do encontro missionário (cultural) com as "religiões" e as "civilizações" americanas.

Ao analisar o problema em relação aos pressupostos 'fideísticos' da cultura missionária, com sua inevitável confusão na definição de 'crenças', 'religião' e 'fé', e levando em consideração a finalidade e o caráter instrumental dos textos catequéticos, deveremos ter sempre presentes, todavia, alguns importantes aspectos distintivos e esclarecedores dos textos em seus contextos ${ }^{26}$.

O que importa, finalmente, é que o catecismo (e sua leitura) representa sempre, necessariamente, a parte de um todo mais amplo, que deveremos levar

${ }^{25}$ SABBATUCCI, Dario. Op. Cit., pp. 13-15. 
em consideração para contextualizar o próprio texto catequético. Além do mais, às vezes podemos encontrar um esboço do contexto em que se insere a obra, justamente em sua parte introdutória ${ }^{27}$. Mesmo assim, esse eventual trabalho de contextualização é sempre particularmente reduzido, em relação a uma contextualização histórica geral: seja porque isso não faz parte, propriamente, dos objetivos do texto catequético; seja porque o autor, em sua posição de missionário, não pode elevar-se, por além de sua condição, quando não há o específico, às vezes necessário, interesse em ocultar tal contexto.

Além do mais, no caso concreto da evangelização americana ${ }^{28}$, nas instruções sobre "como fazer catequese", não há coisa mais importante a ser levada em consideração do que a "inconstância da alma selvagem" ${ }^{29}$ ou, dito de outra forma, a aparência de certas conversões que, às vezes, manifestando-se segundo as formas externas de um cristianismo que significava a aceitação obsequiosa

\footnotetext{
${ }^{26}$ A catequese não se identifica, pura e simplesmente, com o catecismo. Em primeiro lugar, devemos levar em consideração algumas características gerais do contexto (sempre historicamente determinado) dentro do qual o homem (cristão) é impelido a uma ação catequética (evangelizadora), e no qual se coloca a especificidade instrumental do texto catequético. Em decorrência do contexto, encontramos vários dados que se referem à ação da catequese: observações relativas à explicação do catequista, à forma concreta de torná-la clara, às dificuldades que o catequista pode encontrar no seu ensino, às eventuais objeções que pode despertar perante seu auditório, à rejeição ou à aceitação implícitas na ação evangelizadora e que nem sempre são facilmente perceptíveis pelo catequista, etc. A importância e prioridade desses pressupostos pedagógicos e propedêuticos, do texto catequético, para com os próprios "mestres" da doutrina, são evidentes desde o De Catechizandis Rudibus de Santo Agostinho. Desde esse notável exemplo teórico-prático modelar, a incumbência pedagógica se destaca por seu caráter pastoral, enquanto destinada a esclarecer tanto a metodologia do ensino, quanto os aspectos gerais ou específicos da doutrina cristã: em breve, em breve, o texto catequético tem que responder, também, à pergunta “como fazer catequese?". Santo AGOSTINHO. De Catechizandis Rudibus. Tradução italiana de G. Vigini. Milão: San Paolo ed., 1998.

${ }^{27}$ Cf. AGNOLIN, Adone. Op. Cit., (As introduções dos catecismos publicados), pp. 46-52. ${ }^{28}$ Mas não só: vejam-se os caso da Índia, das Filipinas e do Extremo Oriente.

${ }^{29}$ A expressão ganhou uma certa notoriedade nos estudos antropológicos que se referem ao Brasil, desde o artigo de VIVEIROS DE CASTRO, Eduardo. "O mármore e a Murta: sobre a inconstância da alma selvagem”. In: Revista de Antropologia. São Paulo, USP, 1992, v. 35, pp. 21-74. Por outro lado, nesse artigo, a expressão é tirada do Sermão do Espírito Santo do Pe. Antonio Vieira: "a gente destas terras é a mais bruta, a mais ingrata, a mais inconstante, a mais avessa, a mais trabalhosa de ensinar de quantas há no mundo [...]. Outros gentios são incrédulos até crer; os brasis, ainda depois de crer, são incrédulos". No final das contas, a expressão só torna emblemático, na vocação do célebre "imperador da língua portuguesa", um motivo presente ao longo de toda a literatura jesuítica sobre os índios do Brasil, desde a chegada dos primeiros inacianos: a dificuldade da conversão dos indígenas (tupi).
} 
da preponderância econômica, política e cultural da sociedade à qual pertenciam os missionários ${ }^{30}$, ocultava a fragilidade da conversão (a murta de que eram feitas essas "estátuas indígenas", o sermão de Vieira). Por outro lado, mais uma vez, esse risco está presente, também, nas "instruções agostinianas" 31.

Em relação à "inconstância indígena” - esse fácil dobrar-se dessas nações indígenas “à doutrina da fé" em contraposição a um “coração que crê", de fato-, são várias as denúncias que podemos encontrar entre os jesuítas, desde o começo da missão no Brasil. E é paradigmático que, além dessas denúncias, freqüentes ao longo da ação evangelizadora dos jesuítas, encontremos a sinalização desse perigo também na obra de autores franciscanos, por exemplo no México, que sucessivamente ao fracasso da estratégia dos batismos em massa, chamam a

\footnotetext{
${ }^{30}$ No que diz respeito a esse problema, vale a pena relevar a importância da obra de: GLIOZZI, Giuliano. Differenze e Uguaglianza nella Cultura Europea Moderna. Nápoles: Vivarium, 1993. O autor reconduz o mito do 'bom selvagem' à discussão acerca do colonialismo, que se desenvolveu na França no início dos anos de 1870 (cf., a esse respeito, a primeira parte da obra, "Il 'mito del buon selvaggio': prospettive storiografiche", pp. 23-119). Nesta perspectiva, a imagem dos selvagens que viajantes, políticos e missionários do Quinhentos e Seiscentos nos transmitiram pôde aparecer benévola somente se não se leva em consideração os instrumentos culturais com os quais eles tiveram que interpretar as novidades que encontraram. E se na Bíblia, considerada o quadro histórico geral da civilização européia cristão, se encontrou a resposta acerca das origens daquelas populações, segundo Gliozzi é possível compreender as escolhas entre as alternativas oferecidas pelo texto bíblico: elas refletiam as diversas formas de colonialismo, os problemas que elas encontravam e as "razões" que era necessário inventar para justificá-las. Enfim, para o autor, aquelas que foram levadas em consideração enquanto explicações mitológicas ou sonhos coletivos eram, de fato, "ideologias historicamente determinadas". Essa última definição decorre do outro fundamental trabalho, de GLIOZZI. Adamo e il Nuovo Mondo: la nascita dell'antropologia come ideologia coloniale - dalle genealogie bibliche alle teorie razziali (1500-1700). Florença: La Nuova Italia, 1977. Síntese exposta, sobretudo, à p. 4.

${ }^{31}$ As quais sublinham como: "Se [alguém] quer tornar-se cristão porque espera alguma vantagem por parte de pessoas às quais pensa não poder fazer coisa grata de outra forma, ou para evitar problemas por parte de gente que teme ofender e tornar-se inimiga, na realidade não quer, de fato, tornar-se cristão, mas somente fingir sê-lo. Porque a fé não é dada por um corpo que se dobra (sujeita), mas por um coração que crê" (Santo AGOSTINHO. Op. cit., pp. 27-28: Instruções para a Catequese, 5.9). E as instruções tecem, também, uma estratégia: "Caso tenha-se apresentado com falsa intenção ("Ficto pectore"), somente para obter favores humanos ou para evitar problemas, não há dúvida que mentirá. Devemos, todavia, principiar partindo, justamente, do que ele diz mentindo, sem todavia rejeitar sua mentira [...] [e emergindo uma sua] resposta não conforme às disposições de espírito de quem está por ser iniciado na fé cristã, é necessário repreendê-lo com modos doces e afáveis, como pessoa inexperta e inculta..." (Idem, Ibidem).
} 
atenção para este fato. Essa é a situação evidenciada, entre outros, por Bernardino de Sahagún:

“... en todas partes y en las más porfíam de volver a cantar sus cantares antiguos en sus casas o en sus tecpas (lo qual pone harta sospecha en la sinceridad de su Fee christiana) porque en los cantares antiguos, por la mayor parte se cantan cosas Idolátricas en un estilo tan obscuro que no hay quien bien los pueda entender sino ellos solos; y otros cantares usan para persuadir al pueblo a lo que ellos quieren, o de guerra o de otros negocios que no son buenos, y tienen cantares compuestos para estos, y nos los quieren dexar". ${ }^{32}$

Essa "guerra de costumes" re-propõe, implicitamente, a estratégia esboçada pelo próprio texto agostiniano. E é o Pe. Nóbrega que justifica, exemplarmente, a estratégia - que às vezes expunha os missionários a censuras - aplicada pelos jesuítas no Brasil.

"Se nós abraçarmos com alguns costumes deste gentio, os quais não são contra nossa fé católica, nem são ritos dedicados a ídolos, como é cantar cantigas de Nosso Senhor em sua língua pelo tom e tanger seus instrumentos de música que eles usam em suas festas quando matam contrários e quando andam bêbados; e isto para os atrair a deixarem os outros costumes essenciais (...); e assim o pregar-lhes a seu modo em certo tom andando passeando e batendo nos peitos, como eles fazem quando querem persuadir alguma coisa e dizê-la com muita eficácia; e assim tosquiarem-se os meninos da terra, que em casa temos, a seu modo. Porque semelhança é causa de amor. E outros costumes semelhantes a estes". ${ }^{33}$

Essa mesma estratégia, bem descrita por Vasconcelos em relação às pregações do Pe. Azpilcueta Navarro, mostra de forma paradigmática quanto

\footnotetext{
${ }^{32}$ SAHAGÚN, Bernardino de. Psalmodia Cristiana. México 1583: prólogo ao leitor (f. 2v.3r). Citado por ICAZBALCETA, J. García e MILLARES, A. Bibliografia Mexicana del Siglo XVI. México: Fondo de Cultura Económica, 1981, 2ª ed., p. 249.

${ }^{33}$ Carta de Manuel da NÓBREGA a Simão Rodrigues, 17 de setembro de 1552. In: Monumenta Brasiliae, vol. I, pp. 407-408.
} 
a "retórica" indígena despertou a atenção missionária e, portanto, quanto ela está presente em suas pregações.

"Começava a despejar a torrente da sua eloquiência, levantando a voz e pregando-lhes os mistérios da fé, andando em roda deles, batendo o pé, espalmando as mãos, fazendo as mesmas pausas, quebras e espantos costumados entre seus pregadores, pera mais os agradar e persuadir". ${ }^{34}$

Seleção e adoção de costumes indígenas, portanto, para enraizar neles e impor-lhes um novo sentido: esta pareceu uma forma de cimentar o crer indígena ao redor da doutrina cristã, uma forma de transformar a murta em mármore. Não se trata, todavia, de uma operação nova na estratégia jesuítica de evangelização: de alguma forma, assistimos, de fato, à reedição de uma estratégia já apontada, em algum lugar, pelo próprio Inácio de Loyola que convidava a "entrar com a [razão] deles [dos outros], para se sair com a nossa". O problema permanece em saber se, ao invés de sair dessa situação com uma razão (doutrinária) ocidental, não se saiu (necessariamente) com uma terceira: um "encontro" (inevitavelmente) tecido de equívocos, implicitamente reconhecidos. E, neste caso, trata-se de pensar se o mal-entendido não se constitua, realmente, como uma experiência fundante e fundamental da comunicação inter-cultural ${ }^{35}$.

De fato, o pressuposto universalista da missão leva, implicitamente, à necessária constituição dessa comunicação inter-cultural - imposta pelas intenções da evangelização que impõe uma convivência necessária com a diversidade cultural -, a fim de conhecer a peculiaridade de sua(s) forma(s) de comunicação. Isso porque, antes de converter os gentios, os missionários deviam "converter o Evangelho" segundo a cultura local; sucessivamente, eles deviam "converter" a cultura local para dentro da perspectiva universalista ocidental, com a pretensão de "compreender" a economia da alteridade dentro da própria ordem cultural: é justamente na perspectiva universalista ocidental que esse esforço de conversão/tradução, para fora (a tradução do Evangelho) e para dentro (a

\footnotetext{
${ }^{34}$ VASCONCELOS, Simão de. Crônica da Companhia de Jesus. Vols. I-II. Petrópolis: Vozes, 1977 (1663), vol. I, p. 221.

${ }^{35}$ Pela qual problemática, apontamos, entre outros, para o trabalho de LA CECLA. Franco. Il Malinteso: antropologia dell'incontro. Roma-Bari: Laterza, 1998.
} 
tradução da alteridade), encontra a chave fundamental que permite criar, de alguma forma, essas possibilidades de tradução ${ }^{36}$. Todavia, este universalismo deriva diretamente do percurso histórico ocidental pouco acima apontado que leva do universalismo do Imperium (romano), enquanto imposição de civilizar o mundo segundo o modelo da civitas romana, para o universalismo que, tornando-se modelo de uma Monarchia Universalis, torna o orbis, necessariamente, Christianus: impondo-lhe, portanto, a ação de converter seus habitantes, segundo esse modelo. E, a esse respeito, o próprio instrumento jurídico formal do requerimiento americano, elaborado pelo jurista espanhol Juan de Palacios Rubios ao redor de 1512, nos fornece o exemplo mais significativo do produto desse modelo: usado em situações práticas de conquista, ele era ritualmente lido em espanhol ou latim impondo, além da linguagem, a doutrina de uma Monarchia Universalis absolutamente incompreensível para os indígenas. A conversão dava-se, portanto, também no plano jurídico, que constrói suas necessárias doutrinas de forma inevitavelmente entrelaçada com o plano teológico mais geral. No novo imperativo de um orbis Christianus, o próprio Juan de Palacios Rubios apontava, consequientemente, tanto para a "teologia do requerimiento", quanto para a dificuldade indígena de sua compreensão:

"Meu Senhor, parece-me que estes indígenas sejam insensíveis à teologia deste requerimiento e que não haja ninguém em condição de fazer com que o compreendam; não gostaria Vossa Excelência de ficar com ele até que tenhamos colocado na gaiola um desses indígenas, de modo que possa aprendê-la [essa teologia] a seu cômodo e meu Senhor Bispo possa explicá-la?"37

Quase caçoando do modo em que podia, de alguma forma, impor sua compreensão, o autor revela a dificuldade que só a "gaiola" do processo histórico do encontro teria permitido superar. De qualquer modo, o documento respondia às exigências da conquista e contribuiu para aliviar a consciência da realeza.

Esse documento, portanto, destaca-se dentro da perspectiva universalista apontada: essa última revela-se enquanto instrumento fundamental de uma

\footnotetext{
${ }^{36}$ Termo, neste caso, fortemente caracterizado por sua etimologia latina tra-ducere.

${ }^{37}$ Citado em HANKE, Lewis. The Spanish Struggle for Justice in the Conquest of America. Boston: Little Brown, 1965, pp. 33-34.
} 
possibilidade de tradução "para" e "do" outro culturalmente diferente e encontra seu momento mais representativo de constituição na hora em que se passa de um conceito de religião romana, fundamentada na pietas (que constrói o homem, culturalmente romano), para um conceito (religioso) de cristão, que não pode mais ser conotado culturalmente, mas somente através da extensão da fides: esta, e não mais a própria cultura, produz o cidadão da (nova) civitas Dei (de agostiniana memória).

$\mathrm{O}$ (s) mal-entendido(s) da comunicação inter-cultural, que o Ocidente enfrentou, enraizaram-se, portanto, nessa dimensão peculiar de seu percurso histórico que, todavia, apesar de seus contínuos equívocos e reajustes, tornou possível essa comunicação. Nesta dimensão nasceu, de fato, no sentido mais amplo da expressão, a perspectiva antropológica: esta fundamentará a prática de uma disciplina construída, principalmente, sobre esses equívocos e sobre sua possibilidade de um entendimento, de uma explicação.

Mas, no momento do encontro, esse processo de conversão/tradução estabeleceu-se, necessariamente, também do lado da perspectiva indígena que, todavia, distinguia-se daquela ocidental por seus paradigmas mítico-rituais. Neste sentido o impor-se (ocidental) da "com-versão" criou uma necessária e inevitável "com-vergência" (recíproca e, todavia, distinta) na qual os mal-entendidos multiplicaram-se: tanto uma, quanto a outra das partes envolvidas tornaramse, ao mesmo tempo, produtoras, vítimas e beneficiárias desse processo de comunicação, constituído por equívocos e mal-entendidos. Os missionários procurarão, por longo tempo, uma pietas peculiar das culturas indígenas - mais do que uma "religião", um sistema de "crenças" - para poder construir, segundo o modelo oferecido pelo mundo romano, o percurso de um cristianismo que possa levar à fides: trata-se, no fundo, da preocupação própria e constante da catequese. Por outro lado, a fides missionária podia tornar-se, para os indígenas, um instrumento de negociação, na medida em que, segundo seus paradigmas culturais de ordem mítico-ritual, os gestos "resolviam" as intenções recônditas de uma consciência e de uma "religião do coração" que não podiam (não tinham os instrumentos culturais para) conceber. Nessa perspectiva, a "simulação" indígena era a única possibilidade para o indígena agradar, de algum modo, a exigência missionária: daqui a acusação de inconstância e fragilidade desse processo de conversão. E não será por acaso que a característica específica do texto catequético consistirá em sua contínua repetitividade por parte do catecúmeno indígena: tratava-se, de fato, de construir ex novo uma forma peculiar, ao mesmo tempo e correlativamente integradas, da memória e da consciência, para medir, 
de algum modo, um nível "tranqüilizador" em relação à apresentação da fé, na espera de que o catecúmeno, partindo de um "saber" que teria que emanar do texto, pudesse chegar, finalmente, a "possuí-lo" em termos de convencimento e de efetiva (isto é, não ritualista) assimilação doutrinal.

Levando em consideração as perspectivas culturais (e estruturais) peculiares que condicionam esse encontro catequético (uma verdadeira "inculturação $d a$ fé") vamos agora, finalmente, abordar alguns importantes aspectos distintivos e, esperamos, esclarecedores desses textos em seus contextos.

\section{Os Sacramentos entre os Tupi: mediações simbólicas e cultura indígena}

No início do capítulo V de A Escrita da História, Michel de Certeau aponta como:

"quatro noções parecem organizar o campo científico cujo estatuto se fixa durante o século XVII e que recebe de Anpère o seu nome de etnologia: a oralidade (comunicação própria da sociedade selvagem ou primitiva, ou tradicional), a espacialidade (ou quadro sincrônico de um sistema sem história), a alteridade (a diferença que apresenta um corte cultural), a inconsciência (estatuto de fenômenos coletivos referidos a uma significação que lhes é estranha e que não é dada senão a um saber vindo de algures). Cada uma delas garante e chama as outras. Assim, na sociedade selvagem, exposta à vista do observador como um país imemorial (...), supõe-se uma palavra que circule sem saber a quais regras silenciosas obedece. Corresponde à etnologia articular estas leis numa escrita e organizar este espaço do outro num quadro de oralidade. [...] Este quadrilátero "etnológico" [...] tem [...] seu corolário na historiografia moderna, cuja construção apresenta, na mesma época, quatro noções opostas: a escrita, a temporalidade, a identidade e a consciência". ${ }^{38}$

Tendo em vista o objeto de nossa indagação, nos parece de grande relevo a análise que pode ser construída em relação à especularidade desse "quadrilátero etnológico" que emerge exemplarmente no começo da Idade Moderna e que deve ser levado em consideração através de uma prática que se estabelece como ponte fundamental para essa leitura especular que é a etnologia: trata-se da

\footnotetext{
${ }^{38}$ DE CERTEAU, Michel. A Escrita da História. Rio de Janeiro: Forense Universitária, 1982, p. 211 [ed. orig. francesa, Paris: Gallimard, 1975].
} 
prática de tradução. E, repare-se bem, quando falamos em tradução entendemos sim o processo através do qual, de alguma forma, se traz para dentro do próprio mundo cultural uma cultura longínqua, mas entende-se, também e ao mesmo tempo, os instrumentos culturais que permitem, antes dessa (propriamente dita) tradução, uma incursão na cultura outra a fim de conceituá-la.

Na perspectiva específica de nossa indagação, esse processo encontra-se ulteriormente complicado: traduzindo para os indígenas americanos os dogmas doutrinais pós-conciliares, os missionários empreendiam uma tradução de uma tradição religiosa ocidental para uma cultura que não era partícipe dessa tradição. Para poder realizar sua tarefa, o missionário devia tentar entender, portanto e a priori, os códigos culturais daquela cultura nos quais pudesse inscrever sua própria tradição (religiosa).

Além do mais é claro que, se a tradição da catequese se estabelece num plano universal (teleológico), subordinando a esse, segundo seu ponto de vista, a própria história, por outro lado, segundo o nosso ponto de vista, a relação entre história e catequese é, antes de mais nada, um problema interno à perspectiva histórica. A partir daqui, resultam claramente pertinentes as perguntas que o próprio Certeau coloca na abertura de seu trabalho: "Qual é o significado histórico de uma doutrina no conjunto de um tempo? Segundo quais critérios compreendê-la? Como explicá-la em função dos termos propostos pelo período estudado?"39. Se, em relação a essas perguntas, já apontamos algumas propostas de indagação, na especificidade da nossa indagação deveremos, agora, tentar responder a difíceis perguntas ulteriores em relação à peculiar situação de "mediação cultural" realizada pelos missionários (jesuítas) em terras americanas. E essas perguntas dizem respeito, justamente, às modalidades segundo as quais a escrita, a temporalidade, a identidade e a consciência puderam tentar se inscrever nas culturas indígenas, ao mesmo tempo em que esse quadrilátero etnológico tentava transcrever para dentro do mundo ocidental a oralidade, a espacialidade, a alteridade e a inconsciência do mundo indígena americano. Falamos em tentativa de inscrição e de transcrição, não para negar a possibilidade que isso possa ter ocorrido (as representações partilhadas tornam-se, de fato, realidade), mas para abrir um espaço fundamental para a indagação que é, justa-

${ }^{39}$ Idem, Ibidem, p. 33. 
mente, o espaço de uma negociação implícita nos processos de encontro cultural. E isso implica, de alguma maneira, a tentativa de debruçar-se "sobre a construção do sentido do Outro, ou seja, sobre os códigos colocados em jogo, de um e de outro lado do encontro colonial, para entender a alteridade humana, que penetrava de uma forma tão inusitada e violenta no mundo e no fluir da história, criando para tanto novos universos simbólicos com os fragmentos dos tradicionais" ${ }^{40}$. Trata-se, enfim, de entender (entrever) o verificar-se de convergências de horizontes simbólicos enquanto construções históricas que se realizaram no impacto colonial: isto é, entender o processo de seleção, absorção e transformação de elementos/estruturas culturais outros, nos respectivos dois lados do encontro, na medida em que esses elementos faziam sentido para a cultura (indígena ou missionária) que os recebia e/ou eram transformados nessa direção. E se, no momento do encontro traumático, o sentido era diferente, a cultura colonial acaba, de fato, implementando-se nesse processo de convergência que a transforma numa "cultura híbrida"41 ou "mestiça" ${ }^{42}$. E, vale destacar, até mesmo algumas peculiares categorias de análise (ocidentais), que serviram para interpretar a alteridade nesse processo histórico de encontro desenvolvido no interior do Ocidente, constituíram-se enquanto características "categorias híbridas": é o caso emblemático do próprio conceito de "religião".

Mesmo visando investigar, especificamente, às modalidades do encontro doutrinal, por outro lado, todavia, não podemos perder de vista o fato de que essa especificidade do encontro retalha um seu espaço particular dentro de um panorama histórico complexo, como por exemplo, aquele do Brasil colonial onde Colonos, Coroa, administradores e missionários estabeleceram alianças ou travaram lutas em torno da condição básica para a colonização da América Latina: a conquista do trabalho escravo. Nesse específico contexto histórico, as missões jesuíticas ocuparam um lugar estratégico ao se constituírem como

\footnotetext{
${ }^{40}$ POMPA, Cristina. Religião como Tradução: missionários, Tupi e “Tapuia” no Brasil Colonial. São Paulo: Edusc, 2002, p. 24.

${ }^{41}$ VAINFAS, Ronaldo. A Heresia dos Índios: catolicismo e rebeldia no Brasil Colonial. São Paulo: Cia. das Letras, 1995.

${ }^{42}$ GRUZINSKI, Serge. La Guerre des Images: de Christophe Colomb à "Blade Runner" (1492-2019), Paris, Fayard, 1990; GRUZINSKI, Serge e BERNAND, Carmen. De la Idolatria: uma arqueologia de las ciencias religiosas. México: Fundo Econômico de Cultura, 1992 [ed. original francesa de 1988].
} 
poder moderador nessa disputa pelo trabalho. Apesar de sua peculiar posição, os inacianos acabaram se tornando, necessariamente, instrumentos da política de desenvolvimento da Colônia, servindo, portanto, aos interesses da Coroa portuguesa: nessa perspectiva a catequese e, mais geralmente, a obra dos jesuítas no Brasil se caracteriza também por procurar um método alternativo de conquista e assimilação dos povos nativos, os "negros da terra". ${ }^{43}$

Ora, este método alternativo identificou-se com uma operação de "redução" das culturas indígenas que, antes de institucionalizar-se nos famosos modelos alternativos da organização social que levam esse nome, destacou-se como prática necessária de um seu reconhecimento e indagação. Os primeiros reconhecimentos - a leitura e interpretação das culturas indígenas, que devia fundamentar o novo ponto de equilíbrio entre catequese e civilização - parecem delinearse, decididamente, em forma de excessos, por um lado, e de ausências, por outro. Num primeiro tempo, os excessos serão identificados com os costumes e as ausências com as crenças: e, no imperativo de cristianizar os indígenas, os primeiros parecem, em princípio, ter preocupado mais do que as segundas.

Os excessos indígenas identificavam-se, sobretudo, com o conjunto de "costumes abomináveis" ou "maus costumes" (cauinagem, guerra, antropofagia, sexualidade desordenada, pinturas, danças etc.) que conotava um estágio (de aristotélica memória) inferior de humanidade ${ }^{44}$, revelador de uma profunda desordem social e que dificultava, a um tempo, o próprio processo de civilização, fundamento irrenunciável para a sucessiva obra de cristianização. No combate a esses institutos, assim como à instituição central da cultura tupi do karaíba, os "redutores" jesuítas, serão sempre irredutíveis.

"Os impedimentos que há para a conversão e perseverar na vida cristã de parte dos índios, são seus costumes inveterados [...] como o terem muitas mulheres; seus vinhos em que são muito contínuos e em tirar-

\footnotetext{
${ }^{43}$ Entre os vários trabalhos que abordam essa questão apontamos os de MONTEIRO, John Manuel. Negros da Terra: índios e bandeirantes nas origens de São Paulo. São Paulo, Cia. das Letras, 1994. Cf. pp. 36-37. MONTERO, Paula. A universalidade da Missão e a particularidade das culturas. Apud: MONTERO Paula (Coord.). Entre o Mito e a História: o v centenário do descobrimento da América. Petrópolis: Vozes, 1996. Cf. pp. 86-89.

${ }^{44} \mathrm{Cf}$., a esse propósito, PAGDEN, Anthony. The Fall of Natural Man: the american indian and the origins of comparative ethnology. Cambridge: Cambridge University Press, 1982.
} 
lhos há ordinariamente mais dificuldade que em todo o mais [...]. Item as guerras em que pretendem vingança dos inimigos, e tomarem nomes novos, e títulos de honra; o serem naturalmente pouco constantes no começado e sobretudo faltar-lhes temor e sujeição [...]". ${ }^{45}$

Essa denúncia do Pe. Anchieta é um dos numerosos exemplos que podem ser encontrados nas cartas jesuíticas do final do século XVI, mas que se prolonga, no século sucessivo, nas denúncias de "ações e costumes bárbaros da gentilidade", segundo as palavras do Pe. Vieira.

Neste sentido, na base do processo de catequização impunha-se o trabalho enquanto instrumento de civilização. Tanto os aldeamentos, quanto as 'reducciones' constituíram-se como lugares de trabalho que, como tais, eram finalizados à civilização do indígena americano ${ }^{46}$ : estabilidade, regularidade, hierarquia, tornavam-se instrumentos de uma administração (indispensável) de diferentes temporalidades, que encontravam um de seus mais significativos desafios no controle e ordenação temporal de uma sexualidade indígena que os jesuítas consideravam, mais uma vez, enquanto desordenada e excessiva. O processo (civilizador, antes do que missionário) de redução manifesta, enfim, o domínio político como policiamento endereçado a modificar os (excessos dos) costumes indígenas.

Em contraposição aos excessos dos comportamentos, destacam-se, por outro lado, de forma paralela e correlativa, algumas significativas ausências em relação à memória, à vontade ${ }^{47}$ e à religião ${ }^{48}$ : e isso, apesar do definitivo

\footnotetext{
${ }^{45}$ ANCHIETA, José de. Cartas, informações, fragmentos históricos e sermões (1554-1594). Rio de Janeiro: Civilização Brasileira, 1933, p. 333.

${ }^{46}$ A importância do trabalho enquanto instrumento de civilização - e consequientemente de conversão - foi bem evidenciado por ZERON, Carlos Alberto. La Compagnie de Jésus et l'institution de l'esclavage ao Brésil: les justifications d'ordre historique, théologique et juridique, et leur intégration par une mémoire historique (XVI-XVII siècle). Tese de Doutorado, EHESS, 1998.

${ }^{47}$ Em relação ao problema da "memória" e da "vontade" indígena, cf. os trabalhos de VIVEIROS DE CASTRO, Eduardo. "O mármore e a murta: sobre a inconstância da alma selvagem”, artigo citado e de HANSEN, João Adolfo, a comunicação apresentada em ocasião dos Seminários sobre "Instrumentos da Comunicação Colonial", realizados na Universidade de São Paulo nos dias 24 e 25 de agosto de 2000.

${ }^{48} \mathrm{E}$ em relação a isso, cf. POMPA, Cristina. Religião como Tradução. Op.Cit., principalmente o capitulo 1. (O Encontro e a Tradução), pp. 35-56.
} 
reconhecimento (religioso) da alma aos indígenas americanos. Nessa direção, "se o missionário deve modificar, através da força se necessário, o comportamento e os costumes dos Indígenas para salvá-los, ele deve igualmente fazer com que conheçam a lei de Deus". ${ }^{49}$ Para tanto, se os excessos impunham a disciplina, as ausências reclamavam a doutrina. Uma e outra eram, juntamente, fundamentais para realizar o processo de cristianização. Na ótica de nossa indagação, a tentativa de inscrição da disciplina e da catequização revela-se importante para entender a dificuldade de sua inscrição junto aos indígenas americanos (antes que da tradução de suas culturas para o Ocidente), isto é, a dificuldade de inscrever nas culturas americanas um percurso constituído pela escrita, pela temporalidade, pela identidade e pela consciência (ocidentais) para um mundo outro que era representado por uma pontual diferença em relação a esses instrumentos culturais.

\section{A "Rede Demoníaca": entre excessos e ausências}

A uma primeira abordagem de tal relevante problema, parece-nos que dois foram os instrumentos peculiares de tradução que se afirmaram como essenciais nessa obra de inscrição: a tradução lingüística, junto e paralelamente à conseqüente e fundamental tradução conceitual. E esta última parece identificar-se, decididamente, mais com o instrumento interpretativo do demônio (anhanga), do que com aquele de Deus (tupã). Nessa direção, de acordo com Laura de Mello e Souza ${ }^{50}$, acusamos, sem dúvida, na Terra de Santa Cruz, a forte presença de uma "demonologia" que, além de propor-se enquanto produto histórico de uma representação e de uma administração cultural das novas terras americanas, destacou-se, sobretudo, enquanto imprescindível instrumento para gerenciar, de alguma forma, seu peculiar encontro cultural. Com relação a isso, tanto a língua, quanto o demônio constituíram-se, mais do que em instrumentos de simples e pura inscrição/dominação, em instrumentos que levavam em direção a uma inevitável e perturbadora imersão no mundo da cultura indígena. Tudo

\footnotetext{
${ }^{49}$ CASTELNAU-L'ESTOILE, Charlotte de. Les Ouvriers d'une Vigne Stérile: Les jésuites et la conversion des Indiens au Brésil - 1580-1620. Tese de Doutorado, defendida em janeiro de 1999, junto à "Ecole des Hautes Etudes en Sciences Sociales", Paris, p. 142.

${ }^{50}$ Cf. O Diabo e a Terra de Santa Cruz: feitiçaria e religiosidade popular no Brasil colonial. São Paulo: Cia. das Letras, 1987; e Inferno Atlântico: demonologia e colonização - séculos XVI-XVII. São Paulo: Cia. das Letras, 1992.
} 
isso, antes de se saírem como produto de uma nova, peculiar, dimensão cultural: a cultura colonial, de fato. Isso significa que, dentro dos graves problemas suscitados pelos excessos e pelas ausências da cultura indígena americana, a 'conquista espiritual' encontrou-se na necessidade de formular uma primeira forma de redução dessas culturas, estruturando uma rede interpretativa que lhe permitisse, de algum modo, ler e interpretar as práticas culturais indígenas: tratou-se de uma rede redutora que encontrava ao redor do "demoníaco" a estrutura eficaz e cômoda para poder, mesmo que fosse para condenar, abrir-se ao conhecimento dessas práticas ${ }^{51}$.

O "demoníaco" constituía-se como a rede que, em princípio, oferecia a possibilidade de entender tanto os "excessos", quanto as "ausências" que caracterizavam, aos olhos dos missionários, mas não só, as culturas indígenas. E o "demoníaco" foi instalando-se timidamente numa primeira frágil dimensão que se debruçou nas primeiras descrições da alteridade indígena. Buscando uma sua específica "religiosidade pagã" que permitisse implementar o processo e as estratégias de evangelização já experimentadas em relação às alteridades européias, os missionários viram-se na impossibilidade de identificar (reconhecer) esse modelo de alteridade religiosa. E antes do que o modelo, é sobretudo a dimensão religiosa que parecia faltar completamente ${ }^{52}$.

No mais entusiástico dos casos, esse dado garante a primeira constituição do mito do "bom selvagem". Não é por acaso que as peculiaridades positivas do indígena americano encontram-se, desde o próprio Caminha, na sua

\footnotetext{
${ }^{51}$ Neste sentido, não estamos completamente de acordo com GRUZINSKI, La Guerre des Images, obra citada, p. 31. Cf., ao longo desta obra, a rica análise do autor a respeito das imagens (em suas ambigüidades entre destruição e substituição, intercâmbio etc.) e do imaginário barroco. Neste "intercâmbio desigual", o autor destaca como: "por la vía del trueque las cosas de Europa penetraron en los mundos indígenas mucho más pronto que los conquistadores. [...] Trueque de oro e imposición de imágenes: he ahí ya unidas dos caras de una empresa de dominación dedicada a extenderse por todo el planeta: la occidentalización". Ibidem, p. 51. "Pasado el choque de lo desconocido y la primera interpretación colombina, tentativa y flexible, se efectuó el encuadre (Pedro Mártir), se redujo el campo, se estilizó y se dramatizó la visión, hasta que surgió la 'visión americana', en realidad réplica pura y simple de un déjà$v u$ europeo. La mirada del colonizador colocó sobre lo indígena la red reductora pero eficaz y cómoda de lo demoníaco". Segundo nosso ponto de vista, essa peculiar 'rede redutora' permitiu, muito provavelmente, uma redução menos significativa, em relação às práticas indígenas, do que a 'rede' oposta.

${ }^{52}$ Cf. CLASTRES, Hélène. Terra sem Mal: o profetismo tupi-guarani. São Paulo: Brasiliense, 1978, p. 15. (1 'a ed. Paris, 1975).
} 
docilidade e simplicidade ${ }^{53}$ : a carta do primeiro cronista do Brasil representa, portanto, manifestamente, a base de um projeto propriamente colonial, mas se constitui, também e ao mesmo tempo, enquanto base de um entusiástico projeto missionário: este via no bom selvagem a imagem de uma inocência que lhe permitia entrever a possibilidade de fecundar sua alma virgem. É dessa forma que, pouco depois de sua chegada, o Pe. Manuel da Nóbrega podia afirmar, com um tom manifestamente entusiasta em relação à atuação de seu projeto missionário, que se trata de "gente que nenhum conhecimento tem de Deus, nem ídolos ${ }^{54} \mathrm{e}$, sucessivamente, que "esta gentilidad a ninguna cosa adora" Mas, pouco a pouco, a tabula rasa da cultura indígena devia manifestar-se em toda sua ameaçadora dimensão que arriscava de não permitir, ao mesmo tempo, nem a conversão (religiosa) nem a colonização (política). A ausência (até em seus fundamentos lingüísticos) de fé, lei e rei revelava-se como o perigo do fracasso da empresa colonial global. E, em sua especificidade religiosa, assiste-se, portanto, à transformação da interpretação de Nóbrega, como aparece em sua Carta de 1556, já apontada, emblemática correspondência, não mais de uma (pretensa) interpretação etnográfica, mas, finalmente, de uma desesperadora lamentação.

A possibilidade de constituir a Humanidade enquanto sistema de comparações entre suas específicas formas (hoje diríamos de suas culturas), era ameaçada pela impossibilidade de encontrar uma série de valores (religiosos) comuns que deviam fundamentar a comparação. Essa ausência constituía-se como a impossibilidade de realizar uma autêntica conversão/tradução por parte dos missionários. A própria ação demoníaca caracterizava-se, tênue e timidamente, neste vazio de crenças, como eco das caracterizações que a Idade Clássica e Média haviam projetado nas alteridades da Índia, da Etiópia e da Escandinávia e que se transferia para a América em seguida à expulsão ocorrida na Europa ${ }^{56}$. Mas, nas desnorteantes ausências das terras americanas, o próprio demônio corria o risco de se encontrar sem chão para implementar sua ação. Para fundamentar a possibilidade

\footnotetext{
${ }^{53}$ Necessitando de tudo, o indígena necessita, sobretudo e principalmente, daqueles bens culturais que encontram na "creemça" a base fundamental que o Europeu se sente no dever de impor: cf. CAMINHA, A Carta de Pero Vaz de Caminha: o descobrimento do Brasil. $2^{\mathrm{a}}$ ed. CASTRO, Sílvio (Org.). Porto Alegre: L\&PM, 1987.

${ }^{54}$ Carta de 10 de abril de 1549.

${ }^{55}$ Informação das Terras do Brasil. Agosto de 1549.

${ }^{56}$ Cf. MELLO E SOUZA, Laura de. O Diabo e a Terra de Santa Cruz e Inferno Atlântico, Op.cit. .
} 
de uma autêntica conversão tornava-se necessário, então, a anterior possibilidade de uma "traduzibilidade" (apesar da novidade) da cultura americana. Fazia-se necessário encontrar uma gramática das culturas outras que permitisse lê-las: tratava-se de instaurar, finalmente, uma possibilidade de comunicação que unicamente podia permitir uma (de alguma forma) conversão: deste ponto de vista, adquire uma importante relevância o fato das palavras 'conquista', 'conversão' e 'tradução' encontrarem-se envolvidas numa relação semântica tão estritamente recíproca ${ }^{57}$. E em termos comunicativos, verifica-se uma peculiar determinação lingüística da própria conversão. É assim que os missionários, "in the same way that they bypass the ambiguity of Christianity, they avoid the question of the linguistic determination of conversion"58.

Por outro lado, não podemos perder de vista que tudo isso verifica-se, pontualmente, na perspectiva de uma mediação de um religioso que se estabelece enquanto código comunicativo que devia permitir uma penetração da cultura ocidental nas outras culturas, ao mesmo tempo em que devia permitir uma inscrição das outras culturas num reconhecimento ocidental de sua (eventual) "religiosidade". E também não podemos perder de vista como o mundo simbólico indígena devia ter-se aberto a uma perspectiva de tradução frente à linguagem (religiosa) de mediação simbólica dos missionários, às vezes criando ou ameaçando equívocos de que a estreita convivência, junto com a perspicácia de certos missionários se deram, finalmente, conta. Assim o jesuíta Acosta aponta, sintética e emblematicamente, para os problemas que surgiram ao longo da prática missionária nas Américas: essa experiência manifestava quanto podia ser contraproducente e perigoso falar de "igrejas", "monastérios" e "padres" a povos que não conheciam essas coisas. A lição dessa experiência missionária constituiu-se, portanto, na necessidade de adequar-se ao grau de compreensão dos próprios indígenas: dessa forma, corrigiram-se algumas perspectivas catequéticas iniciais como, por exemplo, algumas características diretrizes anchietanas.

\footnotetext{
${ }^{57}$ RAFAEL, Vicente L. Contracting Colonialism: Translation and Christian Conversion in Tagalog Society under Early Spanish Rule. Ithaca: Cornell University Press, 1988. Em relação a essa estrita correlação entre os três termos, cf. principalmente todo o 'Prefácio', pp. IX-XIII. ${ }^{58}$ Idem, Ibidem, p. 6.
} 
Portanto, como ao longo de seu percurso histórico (melhor, do percurso histórico que ele determinou) e com uma destacada atenção perante a novidade do encontro americano, o instrumento conceitual "religião" modelou-se, mais uma vez, manifestando sua vocação no constituir-se como resultado privilegiado de uma comunicação inter-cultural. A projeção das categorias religiosas ocidentais - já produto da peculiar comunicação inter-cultural de uma história (religiosa) que se desenvolveu ao redor do Mediterrâneo - nas outras culturas re-fundavam (religiosamente) suas hierarquias de sentido: mas não podemos deixar de observar como essa tradução devia constituir-se como recíproca, na medida em que a cultura indígena podia transformar o sentido missionário das "igrejas", dos "monastérios" e dos "padres", a que se refere a preocupação acostiana.

E, junta e paralelamente ao conceito de religião, é o processo de personificação dos seres extra-humanos que se constitui como o emblema mais significativo do resultado de comunicação inter-cultural. A construção (conceitual) religiosa encontra, quase, nesses últimos, os tijolos que a edificam. Nessa perspectiva, parece-nos, por exemplo, que o problema do (conceito) "pecado", que se destaca na catequese missionária tupi e guarani, adquire nela uma sua significativa relevância e que, portanto, pode ser tomado como um dos exemplos mais significativos de sua característica e específica relação com o conceito religião, por um lado, e com a personificação extra-humana do demônio, por outro. Analisando essa relação, pretendemos encontrar a significação da ação diabólica que procurávamos, junto aos primeiros missionários, enquanto implementação de sua ação.

Da "ausência" desprendia-se a imagem edênica do Novo Mundo, do "excesso" desprende-se, agora, a imagem infernal. O Demônio torna-se o grande antagonista do processo missionário em terra americana ${ }^{59}$ e a missionação vem a corresponder, em seu fundamento inicial, ao mesmo processo de civilização. É dessa forma que o aldeamento jesuítico constituiu-se como uma solução local da obra, ao mesmo tempo, missionária e civilizadora, representando o mesmo esforço de adaptação à situação econômica, política e religiosa que caracterizava a Colônia. $\mathrm{O}$ aldeamento dos indígenas impunha-se, desse ponto de vista, como

\footnotetext{
${ }^{59}$ Cf. MELLO E SOUZA, Laura de. O Diabo e a Terra de Santa Cruz e Inferno Atlântico, Op.cit.; VAINFAS, Ronaldo. A Heresia dos Índios. Op.cit.; RAMINELLI, Ronald. Imagens da Colonização: a representação do índio de Caminha a Vieira. Rio de Janeiro/São Paulo: Zahar/Edusp-Fapesp, 1996.
} 
criação institucional em vista de uma necessária educação que só poderia levar a (fundamentar) uma conversão. No caso dos costumes indígenas americanos, tratava-se, portanto, de realizar, antes, uma forma de policiamento ${ }^{60}$ a fim de poder, só sucessivamente, realizar uma verdadeira conversão. A catequese oferecia-se, justa e peculiarmente, como o elo do processo entre as duas instâncias. Nesta direção, civilizar, antes de converter, os costumes indígenas nas pequenas “cidades de Deus" - não só catequeticamente afins à civitas Dei agostiniana significava, de fato, reduzir os excessos dos costumes selvagens. Não só, portanto, retirar e afastar os indígenas da costumeira vida itinerante e/ou do perigoso convívio com os colonos, mas também e sobretudo exercer, através da educação dos corpos e das almas, o "bom governo" e "conduzi-los", "reduzi-los" de fato, para a humanidade civil.

Como dizíamos anteriormente, a "escravização" das almas indígenas encontrava seu protagonista no Demônio que, além de configurar-se enquanto antagonista do trabalho missionário, necessitava fundamentar sua ação em "falsas crenças" dos indígenas. "Excesso" e "falsidade" resumem os códigos clássicos da definição do outro pagão. É nessa perspectiva que a "gramática da idolatria" tornou-se o primeiro fundamento de um "crer" que, antes do aparecimento da empresa colonial e missionária, caracteriza-se, como vimos acima, por ser sem alternativas. Mesmo que, pelo fato de não encontrar ídolos, templos e sacerdotes entre os indígenas americanos, em base à "rede" de Las Casas se possa falar de "grau zero" da idolatria ${ }^{61}$, essa idolatria adquire as características de uma "linguagem", isto é, constitui-se enquanto código de interpretação sub specie religionis da alteridade americana, tornando-se, no limite, um esquema universal aplicável a todas as culturas, a partir de uma idéia de religião comum ao gênero humano ${ }^{62}$. Essa idéia de religião e esse seu produto de uma idolatria enquanto linguagem, tornam-se, finalmente, segundo a nossa perspectiva, o fundamento da ação

\footnotetext{
${ }^{60}$ Em relação a este processo, devemos evidenciar a importância desse "aprimoramento civil dos costumes", conforme a análise da obra de Norbert Elias, que é, paralelamente, o "processo civilizador' que manifesta um seu peculiar e intenso desenvolvimento justamente na época renascentista.

${ }^{61}$ BERNAND, Carmen e GRUZINSKI, Serge. De l'Idolatrie: une archéologie des sciences religieuses. Paris: Seuil, 1988, cap. III e passim.

${ }^{62}$ Cf. GASBARRO, Nicola. Il Linguaggio dell'Idolatria. In: Studi e Materiali di Storia delle Religioni, vol. 62, pp. 189-221.
} 
diabólica: se o "grau zero" das culturas apresenta "gradações" específicas nas práticas idolátricas, no caso dos indígenas brasileiros, com suas notáveis "ausências", será justamente essa ação diabólica a representar a linguagem (interpretativa) privilegiada para traduzir suas alteridades.

O Diabo, nas Américas, configura-se, de fato, como primeiro tradutor ${ }^{63}$ dos erros e das falsidades que se apresentam enquanto contraponto correlato da primeira tradução religiosa do mundo americano. Nessa tradução (de costumes, antes do que de crenças) que se estende enquanto território da ação diabólica, os pajés ou caraíbas, os "feiticeiros" para os missionários, tornavamse a imagem de intérpretes principais. Os costumes, impedimento da ação missionária e território da ação diabólica, eram inspirados, de fato, pelas "cerimônias diabólicas", realizadas pelos "feiticeiros". A dificuldade da catequese encontra neles o principal obstáculo, justamente enquanto eles evocam, com suas cerimônias, os antigos costumes: neles se inscrevia a ação demoníaca. Neste sentido podemos também destacar como entre missionários e caraíbas, entre catequese e "cerimônias diabólicas", determinou-se uma "batalha pelo monopólio da santidade" (dos sacra), finalizada à disputa com (e à conquista de) um "poder espiritual" que justificava e até exigia, em suas estratégias, o apoderamento de instrumentos, símbolos, modalidades, falas dos outros ${ }^{64}$.

\section{A Bestialidade da Língua Indígena e sua Catequização}

Mas, mais do que nas "profecias” das cerimônias indígenas, era na própria língua indígena que os missionários descobriam uma "bestialidade" enquanto língua da falta (conceitual) e, no limite, da falta de linguagem. Mais uma vez, repete-se a estrutura antagônica e correlata que caracteriza, aos olhos dos missionários, as culturas indígenas: essa falta (o que antes definimos de "ausências"), ao mesmo tempo em que obscurece a visão do bem - como a ausência da "f", "l" e "r" impedem os institutos da "fé", da "lei" e do "rei" -, ilumina

\footnotetext{
${ }^{63}$ Do latim traducere: o que traz para dentro (o erro no mundo dos indígenas).

${ }^{64}$ Em relação a esse problema, cf. a análise de POMPA, Religião como Tradução, Op.cit., pp. 53-56, onde, em relação ao conflito/encontro entre missionários e caraíbas, se aponta para a "construção negociada" das santidades e dos profetas indígenas, isto é, de uma linguagem "religiosa" enquanto terreno de mediação no qual a alteridade da outra cultura pode encontrar seu sentido e sua "tradução".
} 
sua natureza semper prona ad malum, a ausência (até nos próprios sinais linguiísticos) do bem, produz uma exacerbação (nos costumes) do mal, a falta de uma eqüidade lingüística produz uma gente "absque consilio et sine prudentia" ${ }^{65}$. Nessa direção, antes de enfrentar os problemas postos pela utilização da língua indígena para a constituição dos catecismos jesuíticos, deveremos pelo menos apontar uma primeira significativa identificação, que nos parece emergir em certa literatura jesuítica, entre vernáculo e ação demoníaca. E se, na literatura jesuítica, a língua será "doutrinada" nos catecismos, ela é "caracterizada", por exemplo, nos "autos".

Em nosso trabalho anterior ${ }^{66}$, já reparamos nessa característica dos autos anchietanos. Lá, observávamos como o Pe. Anchieta - que em várias ocasiões sublinhava tratar-se de "gente tão indômita e bestial, que toda a sua felicidade a põem em matar e comer carne humana" ${ }^{67}$ - sintetiza e "reduz" os "maus costumes" indígenas no próprio vernáculo. Se, portanto, o teatro anchietano tornava-se a representação mais significativa da vis combativa (e triunfal) da catequese, ele fundava sua representação nesse específico combate. E esse "teatro poliglota" reservava à língua tupi a voz do demônio que se confunde com aquela de um atento etnógrafo: assim como verificamos, por exemplo, no Auto de São Lourenço, segundo as palavras e a língua que são atribuídas ao chefe dos demônios, Guaixará. Eventualmente, à caracterização de uma descrição ritualística etnograficamente densa, a língua tupi poderá, já nos autos anchietanos, configurar-se como língua, ao mesmo tempo, doutrinada (gramaticalmente) e doutrinadora (nos costumes).

Deste ponto de vista, a própria estrutura do auto de Anchieta manifesta uma característica bastante significativa. Influenciada, de forma marcante, pelo

\footnotetext{
${ }^{65}$ Manuel da NÓBREGA. "Do P. Manuel da Nóbrega ao Dr. Martin de Azpilcueta Navarro, Coimbra-Salvador, 10 de agosto de 1549". In: Serafim LEITE, Monumenta Brasiliae..., op.cit., vol. I, p. 136. No que diz respeito a essa conotação da língua e em relação a seu doutrinamento, veja-se, também, a comunicação de João Adolfo HANSEN, apresentada em ocasião dos Seminários sobre "Instrumentos da Comunicação Colonial", op.cit.

${ }^{66}$ AGNOLIN, Adone. "Mediações Simbólicas e Cultura Indígena: leitura jesuítica das práticas indígenas". In: $O$ Apetite da Antropologia: o sabor antropofágico do saber antropológico. Alteridade e Identidade no caso Tupinambá. São Paulo: Humanitas, 2005, p. 105-31.

67 "Do Ir. José de Anchieta aos Irmãos enfermos de Coimbra (São Vicente, 20 de março de 1555)". Apud: LEITE, Serafim. SJ. Cartas dos primeiros jesuitas do Brasil. São Paulo: Comissão do IV Centenário da Cidade de São Paulo, 1956, vol. II, doc. n. 23, p. 120.
} 
“auto" português de Gil Vicente e de sua escola, manifesta a característica marcante da ação missionária jesuíta que apontamos: isto é, aquela de apropriarse dos repertórios culturais indígenas, mesmo (ou, sobretudo) quando fosse para transformá-los. Em correlação à herança cultural especificamente portuguesa (ocidental), na América portuguesa o auto se constitui na base do ritual indígena de recepção de uma personagem ilustre, o "ere-iur-pe": saudação tupi de recebimento que é significada literalmente pelas palavras (rituais) tupi dessa saudação, isto é, 'tu vieste?" ${ }^{68}$. Sem querer e nem poder entrar aqui no mérito da estrutura dos autos anchietanos, parece-nos útil, todavia, para nossa investigação, observar como a introdução dos assim chamados “demônios" na parte central dessas representações se oferece sempre como espaço, textual e teatral, privilegiado para a encenação do diálogo/disputa entre bem e mal, expressos na língua indígena enquanto condenação de seus “maus hábitos". A língua tupi torna-se, finalmente, nos autos anchietanos, o espaço literário reservado aos institutos culturais que ela própria teria contribuído a instituir. E se nesse espaço literário constitui-se enquanto condenação, ela já se manifesta por uma função profundamente catequética.

Embriaguez pelo cauim, tintura e dança, inspiração do fumo, guerra e antropofagia, adultério (a poligamia). Antes de uma "demonização dos ritos tupis"69, em nosso trabalho citado destacávamos como essas ações tornaram-se "maus hábitos" em decorrência de uma descontextualização cultural destas ações que os missionários tiraram (cortaram) de seu contexto ritual: o culto dos mortos, que dava sentido a essas ações na cultura indígena, nunca aparece a elas associado. Além disso, observávamos que a demonização de determinados costumes indígenas se produziu, justamente, pelo desconhecimento (ou melhor, pelo não reconhecimento) de uma prática religiosa (cultual), denotada e conotada segundo os parâmetros de um conceito específico de religião que representa uma invenção cultural cristã. Isso tornava evidente, para nós, o reconhecimento de um conceito de religião que, não podendo enquanto tal ser isolado de seu contexto cultural, era profundamente diferenciado entre o contexto indígena e

${ }^{68}$ Cf.: Capítulo V da Introdução a: Pe. José de Anchieta S.J. Teatro de Anchieta. In: Obras Completas. Trad., introd. e notas do CARDOSO Pe. Armando. São Paulo: Loyola, 1977. vol. III, p. 51-57.

${ }^{69}$ BOSI, Alfredo. Dialética da Colonização. $2^{\mathrm{a}}$ ed. São Paulo: Cia. das Letras, 1994, p. 68. 
aquele missionário. Todavia, como pudemos verificar acima, tanto o instrumento conceitual religião, quanto o processo de personificação dos seres extra-humanos produziram-se, ao longo de sua história (ocidental), enquanto resultado de uma comunicação inter-cultural: missionários, antes, e etnólogos, depois, projetaram as categorias religiosas ocidentais nas outras culturas e, conseqüentemente, re-fundaram as hierarquias de sentido. Para os jesuítas, as hierarquias de sentido da cultura indígena encontraram na personificação e na ação demoníaca seu instrumento interpretativo e de organização privilegiado. A nova organização e as novas hierarquias da cultura indígena trilhavam, na interpretação missionária, a pré-existente subordinação aos "espíritos" que, de fato, caracterizava essas culturas etnológicas: mas isso foi feito para reconstruí-las dentro da nova situação cultural (doutrinária) católica. É dessa forma que, como no Auto de São Lourenço, também na parte central dos outros autos anchietanos, a comida, a bebida, as práticas sexuais ${ }^{70}$, o fumo ${ }^{71}$, aparecem como características representações dos maus hábitos dos indígenas. E, vale ressaltar, nesse gênero literário, esses hábitos falam (são expressos) na língua tupi.

Era justamente pela "força do hábito (mau)", além que pela inconstância do indígena americano, que a conversão do "triste e vil gentio" pelo convencimento (pela catequese) configurava-se como de difícil alcance. E era para corrigir a força desse hábito que emergia, com o Pe. Manuel da Nóbrega, a estratégia da sujeição enquanto caminho apropriado e necessário para uma, de qualquer forma, possível cristianização:

"Entendo por experiência o pouco que se podia fazer nesta terra na conversão do gentio por falta de não serem sujeitos, e ela ser uma maneira de gente de condição mais de feras bravas que de gente racional e ser gente servil que se quer por medo e sujeição". ${ }^{72}$

Uma "sujeição se impõe a quem sujeito não é", segundo o trocadilho sugerido pelo próprio Nóbrega, uma repressão implacável aos costumes (intole-

\footnotetext{
${ }^{70}$ Sempre estritamente ligadas ao "desregramento" alimentar.

${ }^{71}$ Interessante observar que o verbo fumar em tupi (petymb- $u$ ) significa literalmente "ingerir, comer fumo": algo que insere, estruturalmente, a ação na perspectiva de uma prática alimentar.

${ }^{72}$ Cartas dos primeiros jesuítas do Brasil. LEITE, Serafim (Org.). São Paulo: Missão do IV Centenário da Cidade de São Paulo, 1954. v. I, p. 412; v. III, p. 71-72.
} 
ráveis) dos indígenas, uma "guerra aos costumes" para eliminar o costume da guerra e dos rituais que se desenvolviam a seu redor. "Reduzir" a alteridade do outro se configurava, portanto, além que como uma redução de sua alteridade lida sub specie religionis - que privilegia, nesse específico "grau zero da idolatria" brasileira a ação demoníaca -, como uma "redução política" (um policiamento como redução) que se realizava com a concentração dos convertidos (reduzidos) em aldeamentos organizados. Uma nova organização social que incluía gestos, temporalidades, práticas e, não por último, a língua segundo a qual deviam ser doutrinados.

Enquanto projeção significativa de uma cultura contra-reformista, a "bestialidade" indígena configurava-se para os jesuítas, não mais como vazio cultural a ser, eventualmente, preenchido por sua liturgia coral e pinturesca, mas, ao contrário, como a presença forte e marcante do Demônio que teria imposto "rituais bárbaros" ao "triste e pobre gentio". Para corrigir hábitos produzidos por essa ação, não bastava ensinar a doutrina: a "conversão do gentio" (Anchieta) só podia se dar através de uma sua, anterior, "sujeição” (Nóbrega). Soltos no espaço de uma animalidade onde não agiriam como sujeitos (políticos), os índios americanos tornavam-se "triste e vil gentio" enquanto subjugados por um Demônio que lhes ensinara os abomináveis costumes. E se a língua se tornava o instrumento por excelência da construção do espaço político ${ }^{73}$, tratava-se, antes, de reduzir a língua para, sucessivamente, doutriná-la. Nessa perspectiva, parece-nos bastante significativo o fato de que, na própria documentação de nossa investigação, alguns catecismos em língua indígena "deslizem” para o significativo título (programático) de Catecismos da língua indígena: é, por exemplo, o caso do catecismo de Montoya (Catecismo de la Lengua Guarani) e daquele de Bernardo de Nantes (Katecismo Indico da Lingua Kariris). Reduzir a língua (indígena) significava, de alguma forma, torná-la apta para receber - e, portanto, re-transcrever nela - a catequese (ocidental).

Todavia, reduzir a língua obrigava, de alguma forma, a adotá-la para poder transformá-la. A “indigenização do Catolicismo”, que segundo Lacouture efetivou-se pela habilidade do jesuíta em usar a seu favor a autoridade dos caciques ${ }^{74}$,

\footnotetext{
${ }^{73}$ É extremamente interessante, a este respeito, levar em consideração a importância dessas teorizações presentes nas obras de Aristóteles e Cícero, relidas com especial atenção pelo Humanismo renascentista.

${ }^{74}$ LACOUTURE, Jean. Jésuites: les conquérants. Paris: Seuil, 1991.
} 
realizou-se, antes, justamente no plano lingüístico. Nesse plano, os missionários buscavam a possibilidade de entrever equivalências e, portanto, possibilidades de traduções entre as duas realidades culturais. A apropriação de repertórios culturais indígenas tornava-se, enfim, de grande importância para a eficácia da evangelização. É dessa forma que, por exemplo, impunha-se a tradução do nome de Deus como Tupã ou a do Demônio com vários nomes de "espíritos da floresta" e, no teatro de Anchieta, até mesmo com nomes de personagens históricos que teriam combatido contra os portugueses.

Tudo isso comportava a necessária conseqüência de transformar/traduzir ${ }^{75}$ o conjunto das crenças indígenas para impor uma:

"aculturação católico-tupi [que] foi pontuada de soluções estranhas quando não violentas. $\mathrm{O}$ círculo sagrado dos indígenas perde a unidade fortemente articulada que mantinha no estado tribal e reparte-se, sob a ação da catequese, em zonas opostas e inconciliáveis. De um lado, o Mal, o reino de Anhanga, que assume o estatuto de um ameaçador AntiDeus, tal qual o Demônio hipertrofiado das fantasias medievais. De outro lado, o reino do Bem, onde Tupã se investe de virtudes criadoras e salvíficas, em aberta contradição com o mito original que lhe atribuía precisamente os poderes aniquiladores do raio". E com esse processo cria-se, necessariamente: "uma terceira esfera simbólica, uma espécie de mitologia paralela que só a situação colonial tornara possível". ${ }^{76}$

$\mathrm{E}$ as experiências das reduções foram relativamente bem sucedidas, pois tiveram como resultados tanto as relações sociais concretas representadas pelos aldeamentos, quanto a constituição da cultura paralela e, portanto, de um novo imaginário: essas duas dimensões da realidade encontravam-se, de fato, estritamente interligadas. É a esse respeito, ao analisar a santidade na situação colonial, que Vainfas fala em hibridismo cultural, destacando que "foi, portanto, no plano informal e pragmático dos gestos e nos interstícios e mediações de

75 "Aculturar também é sinônimo de traduzir", como releva BOSI, Alfredo. Dialética da Colonização. Op.Cit., p. 65. Nós diríamos, todavia, que aculturar é, sobretudo, traduzir, uma tradução que se impõe à alteridade traduzida e que lhe impõe de interagir no espaço dessa tradução.

${ }^{76}$ Idem, ibidem, pp. 65-66. 
cada universo de crenças que se foi operando a possível fusão católicotupinambá"77 e que "fora mesmo nos aldeamentos da Companhia que se havia forjado o amálgama entre o catolicismo e a mitologia tupinambá"78, desse modo, índios e jesuítas teciam juntos a teia da santidade.

E, do nosso ponto de vista, esta "santidade" encontrava seu instrumento privilegiado de construção em uma "demonologia" que, contrastivamente, oferecia sua preciosa colaboração na tentativa de defini-la. Se, de fato, o mundo (ocidental) do século XVI sofre uma ausência e reclama a necessidade de refletir a presença de um "Deus [que] não se oferece por inteiro ao olhar, [de fato] Ele [esse Deus] deixa suas marcas no mundo. A tarefa do cristão e particularmente do sacerdote cristão é tentar ler essas marcas que inscrevem nos objetos sua distância e sua diferença do Paradigma. A tarefa do sacerdote cristão missionário é maior. Ele não é apenas um leitor das marcas; deve lê-las e modificá-las. Se a mudança não for possível deve abandoná-las à sua sorte ou - melhor - eliminá-las"79. E entre a tentativa (imposição) cristã de ler "as marcas da distância" e a tarefa do sacerdote missionário de modificá-las (ou eliminá-las), nós não vemos nenhuma diferença significativa. Com efeito, a leitura destas marcas por parte dos jesuítas se traduzia na produção de uma verdadeira e copiosa literatura. Este fato provocava uma profunda reconstituição de práticas e rituais (em medida muito menor, de mitos) que se encontravam recriados e relidos dentro de um contexto lingüístico e cultural completamente novo. Além isso, muitas vezes fragmentos dessas práticas, mitos e rituais tornavam-se simplesmente signos esvaziados de seu próprio universo simbólico e recuperados para articular o novo universo simbólico da tradição ocidental.

Dessa maneira, além da tradução, em todas as suas formas, a escrita (e a leitura) vem a representar a outra grande marca deste processo de aculturação. De fato "uma cultura não-letrada podia, pois, manter uma identidade básica simplesmente conservando a estabilidade de seu vocabulário e de sua sintaxe [...]. Usando um semelhante vocabulário, a pessoa, desde a infância, adquire informações sobre com quem se casar e com quem não se casar, com quem se

\footnotetext{
${ }^{77}$ VAINFAS, Ronaldo. A Heresia dos Índios. Op.Cit., p. 111.

${ }^{78}$ Idem, ibidem, p. 211.

${ }^{79}$ BAËTA NEVES, Luiz Felipe. O Combate dos Soldados de Cristo na Terra dos Papagaios. Rio de Janeiro: Forense-Universitária, 1978, p. 35-36.
} 
unir e com quem não, quem amar e quem odiar, que comer, que usar. Suas expectativas culturais lhe são dadas. Ao usar o termo 'informação armazenada" ${ }^{90}$ incluímos tanto descrição como prescrição. As duas modalidades [de fato] se sobrepõem". Ora, a escrita altera profundamente a codificação inconsciente daqueles que se identificam com o grupo lingüístico, na medida em que "procura elaborar um enunciado especial do que eles seriam, de modo a identificá-los"

Se o processo de aculturação, na preservação da similitude, não faz tabula rasa nem ignora o conjunto de crenças da cultura indígena, a releitura das práticas através da escrita, subtraindo-as à relação direta ou indireta com o rito, torna-se ela mesma rito "no momento em que troca o desvendamento dos sacra e do segredo com o desmascaramento das lógicas coercitivas e impessoais que dominam a vida social e subtraem a identidade ao homem; ou, de outra forma, permanece apenas narração consolatória que contudo não funda de maneira alguma a realidade, enquanto, ao ato fundante, substitui uma promessa de salvação" 82 . Desvendamento e, ao mesmo tempo, não-reconhecimento dos sacra enquanto tais, os rituais indígenas encontram-se esvaziados de suas funções fundantes (identificadoras) através do sistema das analogias e do simbolismo.

Os rituais bárbaros, que teria tornado o gentio tão triste e pobre, eram manifestação da linguagem diabólica. E se a língua indígena constituía-se como o produto dessa sujeição, antes de ensinar a doutrina, devia-se "reduzir" a língua, para cortar os "excessos", antes de doutriná-la para preencher suas "ausências". A primeira operação se identifica com uma "gramatização" (escrita) da língua indígena: trata-se da construção da "língua geral" ${ }^{83}$, não só para o Tupi do Brasil, mas também para o Guarani do Paraguai de Montoya, ou para o Quéchua e Aymara do Perú de José de Acosta.

Mas, ao mesmo tempo em que a língua era reduzida, empreendia-se o esforço paralelo de adotá-la para podê-la transformar. E no esforço contínuo de

\footnotetext{
${ }^{80}$ Que diz respeito à estrutura desse processo implicitamente identitário.

${ }^{81}$ HAVELOCK, Eric A. The Literate Revolution in Greece and its cultural consequences. Princeton: Princeton University Press, 1982. [Trad. port. de O. J. Serra. São Paulo: Unesp/ Paz e Terra, 1994. p. 109.].

${ }^{82}$ SCARPI, Paolo. La Fuga e il Ritorno: storia e mitologia del viaggio. Veneza: Marsilio, 1992. p. 183.

${ }^{83}$ Um esboço dessa análise encontra-se em nosso artigo citado, na parte que se refere a "Conceitos, palavras e gramáticas", pp. 58-65.
} 
buscar equivalências para achar possibilidades de traduções entre as duas realidades culturais, muitas vezes impunha-se a necessidade de criar, ex novo, conceitos - enquanto instrumento de tradução - fundamentais para a mensagem missionária (ocidental) e que não existiam nas culturas indígenas. Nossa investigação procurou detectar alguns dos compromissos lingüísticos (culturais) que encontramos materializados em nossa documentação catequética em língua tupi. Grosso modo, parece que tais compromissos resumem duas estruturas fundamentais em seu modus operandi: uma transformação do significado ("ocidentalizado") em relação ao signo (indígena) e uma inscrição ex novo de um signo e um significado ocidental na cultura indígena. Mesmo que de forma diferente, nos dois casos tornava-se essencial, a fim de realizar essas operações, conseguir dominar (lingüística e culturalmente) os repertórios lingüísticos e culturais indígenas e se apropriar deles. Isso se tornava, de qualquer forma, fundamental para a eficácia da evangelização.

Ainda com relação à subordinação da cultura indígena, será interessante apontar para alguns dos problemas que se desprendem dessa específica perspectiva. A suspeita inicial é de que, para realizar esses fundamentais compromissos (lingüísticos), além e antes da "mitologia paralela" ${ }^{84}$, da qual fala Alfredo Bosi, deva ter-se constituído uma fundamental "ritualidade paralela e transversal" às duas culturas. A "alegoria", contraponto e base da catequese, segundo o autor da Dialética da Colonização, constituiu e produziu a transformação no plano ritual: só esse pareceu oferecer, de fato, as bases cultu(r)ais em condição de produzir a transformação do novo contexto que permitisse traduzir a especificidade da nova invenção/criação lingüística, mitológica e cultural ${ }^{85}$.

Desse modo verificou-se, antes de uma, de qualquer forma, frágil "mitologia paralela", uma evidente e consistente "ritualidade paralela", a respeito da qual se desenvolveu uma peculiar alegoria que produziu a transformação no plano ritual. É nesse quadro ritual (indígena) que se organizou a absorção de elementos cristãos: por outro lado esses últimos não deixaram de plasmarse, de alguma maneira, em relação às estruturas rituais dentro das quais inse-

\footnotetext{
${ }^{84}$ Também porque, mais do que uma mitologia, trata-se propriamente de uma (com)figuração do(s) protagonista(s) das ações "excessivas" (abomináveis, más) a serem reduzidas, e das ações catequísticamente "doutrináveis".

${ }^{85}$ Nova no sentido de inventio latina: produto de uma nova disposição das partes do discurso (e/ou da sua sintaxe).
} 
riam-se para adquirir algum sentido. Nesse deslocamento que apontamos, de uma chave de leitura mitológica para uma ritual, parece confirmar-se uma específica relação estrutural evidenciada pela Escola Italiana de História das Religiões. De fato, partindo da observação de De Martino ${ }^{86}$, segundo a qual, na cosmo-visão indígena, o ritual se configura enquanto instrumento para intervir na realidade e assimilar a mudança, o nosso exemplo e sua ênfase ritual, contrariamente àquela mitológica, parece confirmar, sobretudo, o desenrolar-se da análise proposta por Sabbatucci ${ }^{87}$. Segundo este autor, de fato, enquanto o mito define uma realidade imutável e fundada uma vez por todas, como essencial à condição da humanidade e, portanto, não passível de transformação, o rito tem a função de abrir a possibilidade de intervir na realidade para modificá-la em relação às transformações que historicamente se impõem.

E ainda, nessa perspectiva, é significativo o fato de que, em todos os documentos de nossa indagação, redigidos por missionários, encontra-se de forma bastante evidente uma "identificação" nítida entre o Tupã indígena e a primeira pessoa da Trindade ${ }^{88}$. Essa identificação, aliás, parece constituir-se, muito mais como instrumento lingüístico do que como uma "figura" indígena tupi que realmente pudesse ser pensada, pelos jesuítas, em seu paralelismo com a figura do Deus cristão. Em suma, a "figura" Tupã não parece ter tido a oportunidade de configurar-se enquanto instrumento apto a veicular importantes significados, próprios do Deus cristão: a não ser aquele de uma certa característica irascível, que tem, todavia, uma sua importância estratégica na catequização jesuítica. Essa figura pareceu constituir-se, enfim, enquanto signo apto a tornar-se um bom instrumento para veicular uma significação doutrinária e ritualisticamente preenchível.

Encontramos essa mesma nítida "identificação" em relação ao Demônio (católico) com o Anhanga (tupi). E um outro importante instrumento lingüístico encarregou-se, em sua função doutrinária, de veicular (inscrever) a significação peculiar do Demônio no signo de Anhanga: tratou-se do termo que, para ser traduzido para a língua tupi (para sua cultura), apareceu na obra anchietana

\footnotetext{
${ }^{86}$ DE MARTINO, Ernesto. Il Mondo Magico: prolegomeni a una storia del magismo. Turim: Einaudi, 1948 e La Fine del Mondo: contributo all'analisi delle apocalissi culturali. Turim: Einaudi, 1977.

${ }^{87}$ SABBATUCCI, Dario. Sommario di Storia delle Religioni. Roma: Il Bagatto, 1991, p. 183 e segg. ${ }^{88}$ Excluindo o exemplo do único autor não jesuíta, o franciscano frei Bernardo de Nantes que utiliza, em seu lugar, Inhinho, em relação à cultura Kiriri, pela qual o jesuíta Vincencio Mamiani continua usando a "identificação" de Tupã.
} 
como o mais controvertido: o termo "pecado", antes de impor-se definitivamente com o signo lingüístico tupi angaipaba. Evidentemente, podemos pensar que a inicial circulação do signo lingüístico tupi (e guarani) possa ter criado evidentes problemas para veicular o significado do conceito (ocidental) de pecado. E isso porque devia haver uma clara diferença entre os conceitos de "mal", "maldoso" ou das "coisas da alma perversa" ${ }^{89}$ nas duas diferentes perspectivas culturais. A sucessiva adoção do signo lingüístico tupi indica, segundo nós, o encerramento de uma doutrinação da língua que, com os simultâneos recursos catequéticos, sermonários, mas também poéticos e teatrais, acabou re-plasmando o (velho) signo indígena. Dessa maneira, segundo nosso ponto de vista, a realização da obra, a produção desse peculiar resultado históricocolonial, não se configura tanto num plano mitológico, quanto num plano ritualístico. Assim, o signo Anhanga deverá, de algum modo, sua imposição - sua veiculação mais prenhe de significados em relação ao seu antagonista (missionário) Tupã - enquanto sujeito manipulador, ritualisticamente determinável, desse 'pecado' do qual o indígena é - devia ser representado enquanto - vítima.

\section{A Catequização em Língua Indígena}

É nessa "ritualidade paralela e transversal" que achamos se deva procurar a construção do encontro cultural entre jesuítas (missionários) e selvagens. $\mathrm{O}$ resultado mais significativo desse encontro parece sintetizado de forma emblemática pela postura do jesuíta Acosta segundo o qual, a fim de elaborar uma estratégia eficaz de catequese fazia-se necessário, antes, conhecer os costumes dos selvagens: e, de fato, "foi só no cotidiano das aldeias, no confronto permanente com os costumes gentílicos, que as descrições do universo simbólico indígena se tornaram mais 'densas', no sentido de desvendar uma teia de significações em processo permanente de ajuste à realidade" ${ }^{\text {"90 }}$.

A perspectiva da catequese, à base de nossa documentação, nos desperta a suspeita de que esse encontro de ritualidades realizou-se, sobretudo, através

\footnotetext{
${ }^{89}$ Expressões que nos pareceram já o resultado mais evidente das re-transcrições que afetaram profundamente a possibilidade de pensar de forma menos metafísica (ocidental) este conceito de "mal" indígena, para o qual apontamos uma peculiar indicação de tradução de angá ( $t$ up-aba correspondente, de alguma forma, a um "estar deitado da alma", esta última que traduziria de forma problemática o termo angá, que na língua tupi indicaria, propriamente, uma "sombra", que não cabe perfeitamente na materialidade do termo 'alma'.

${ }^{90}$ POMPA, Cristina. Religião como Tradução. Op.cit., p. 341.
} 
dos sacramentos: neles deveremos procurar, na medida do possível, as modalidades (lingüísticas e culturais) que constituíram o momento de encontro e a recíproca reformulação cultural. A "mitologia paralela" torna-se, de conseqüência, apenas o resultado formalizado desse processo.

E a partir desse ponto de vista é importante destacar-mesmo que brevemente, na economia desse artigo - a importância e a centralidade que os sacramentos vieram adquirindo, no interior das reuniões conciliares tridentinas, em sua profunda função de demarcar a ortodoxia doutrinária que, catolicamente e mais do que nunca antes, começava a ser medida pelos atos de fé: testemunhas da peculiaridade dessa fé. Com as novas definições doutrinárias dos sacramentos podemos então delinear seu impacto (mas também as formas de convivências), já anteriormente apontado, com os rituais sociais tradicionais. A peculiaridade americana, e especificamente aquela brasileira, nos permitirá entrever, enfim, analogias e diferenças do mesmo processo. Além do mais, na peculiaridade lingüística da catequese segundo o vernáculo indígena (o texto), não podemos perder de vista o "fazer ritual" (o contexto) que constrói e configura o espaço do encontro.

O exemplo mais geral e representativo, a respeito desse último fundamental problema, nos parece configurar-se, justamente, na estrutura do encontro entre os compromissos lingüísticos (culturais), que se realizam através de duas estratégias: a transformação do significado ("ocidentalizado") em relação ao signo (indígena) e a inscrição ex novo de um signo e um significado ocidental na (estranha) cultura indígena. Nos dois casos, essa operação tornava-se possível na medida em que se constituía como paralela à primeira distinção importante que vimos impor-se no (e impor o) mistério sacramental: como essa última, a primeira também decorria de (fundamentava-se em) uma estrita correlação entre mais termos como, por exemplo, entre marca (signo) e graça (significado), entre visível e invisível, entre material e espiritual, entre ver (o signo) e receber (o fruto) etc. Nossa investigação fez emergir, a esse respeito, alguns exemplos significativos já presentes na catequese jesuítica européia dessa época. ${ }^{91}$

\footnotetext{
${ }^{91}$ Por exemplo, no extenso e importante catecismo do cardeal jesuíta Roberto BELLARMINO. Dottrina Christiana dell'Ill.mo e R.mo Card. Rob. Bellarmino figurata d'Imagini. [In Augusta con licenza de' Superiori appresso Christophoro Mango, 1614]. Edição de 1718: Dichiarazione della Dottrina Cristiana Compofta per ordine di N.S. Papa Clem. VIII. di fel. mem. Dal Rer. P. ROBERTO BELLARMINO Sacerd. della Compagnia di Giesù, poi Cardinale di S. Chiefa del Tit. di Santa Maria in Via. Do ponto de vista doutrinal, a distância cultural indígena podia ser lida como uma ausência de instrumentos lingüísticos-conceituais
} 
Finalmente, em síntese, no instituir-se de uma comparação (de humanidades) organizada por um paradigma (teológico) entrevemos, de alguma forma, o paralelo processo do determinar-se de uma unicidade (modelar) da gramática lingüística (latina e ocidental) que devia permitir, de algum modo, a apropriação (tradução, para o Ocidente, e reconstrução) das línguas indígenas. As duas estruturas paralelas organizam e fundam uma leitura baseada num processo de tradução. Essa estrita associação encontra-se evidenciada, nessa mesma perspectiva, na obra de Vicente Rafael que destaca claramente como a:

"Christian conversion can be said to repeat the process of translation, at least where the missionaries were concerned. Both processes involved the sublation of all signs and speech to the sacred Sign of God, Christ. As the Sign of the Father, Christ stands at the apex of all creation insofar as $\mathrm{He}$ is the perfect fusion of the Father's will and expression. In Christ one has the image of perfect speech, in that in Him everything that has been and will be said has already been spoken. To be converted is to

que eram essenciais para empreender qualquer possível forma de catequese. Apreender os nomes para aprontar as primeiras estruturas significativas desse Mistério significava, antes de mais nada, apreender o "oculto" no "manifesto" e, ao mesmo tempo, uma "unidade" que esse oculto projeta sobre a "diversidade" das coisas manifestas. (BELLARMINO: [1614] 1718: 5-6, fólios A3-A3v). Verdade e divindade impõem-se conjuntamente como unicidade, medida de uma diversidade que não se mede por diferenças de estrutura, mas por afastamento-aproximação a essa medida referencial. E essa medida encontra sua integrativa parte referencial numa, diríamos hoje, "naturalização" desses conceitos: a unicidade da natureza ecoa, no plano do manifesto, a unicidade da "essência infinitamente potente", que se oculta nele. E esse oculto que "des-cobre-se" nas coisas manifestas - porque antes estaria encoberto nelas - parece caracterizar-se como o que Baêta Neves define o "paradigma ausente", mas que do ponto de vista missionário constitui-se, frente à alteridade, enquanto "paradigma estruturante". Na perspectiva missionária, o paradigma torna-se estruturante - com relação à leitura da alteridade cultural - na medida em que: "se Deus não se oferece por inteiro ao olhar, Ele deixa suas marcas no mundo. A tarefa do cristão e particularmente do sacerdote cristão é de tentar ler essas marcas que inscrevem nos objetos sua distância e sua diferença do Paradigma. A tarefa do sacerdote cristão missionário é maior. Ele não é apenas um leitor das marcas; deve lê-las e modificá-las" (Baêta Neves, 1978: 35-36). Todavia, antes da modificação dessa alteridade em relação ao paradigma, o que nos interessa é o fato de que essa leitura da diferença constitui-se como a possibilidade de inserir a alteridade cultural por dentro de uma estrutura paradigmática. Mesmo estabelecendo as diferenças enquanto gradações - qualitativamente denotadas - de um afastamento da sua referencialidade, esse paradigma começa por organizar uma perspectiva antropológica, mesmo que, ainda, subordinada àquela teológica. Frente à relação paradigmática do Sagrado, o conceito de Humanidade fundamenta a possibilidade de criar e estabelecer, finalmente, uma comparação das diferenças, mesmo que ainda submetidas a um julgamento qualitativo. 
recongnize the Sign as the sole and authentic representation of the Father. It is to acknowledge one's words and intentions as therefore derivative of a prior Word". ${ }^{2}$

\section{Os Sacramentos entre os Indígenas}

Ora, como temos apontado acima, tanto em relação à nova situação pósconciliar da Europa - que se estruturava, de fato, ao redor de um prioritário e arriscado (polêmico) problema de tradução bíblica e doutrinária -, quanto em relação à catequese indígena em terra americana, esse problema de tradução tornava-se particularmente explícito e marcante, em termos de controle e reformulação das estruturas sociais tradicionais, justamente no que diz respeito à administração dos sacramentos. O sacramento - isto é, a ação e a relação com os (mas, também, a manipulação dos) sacra - representava o momento (ritualmente determinado) da aproximação mais significativa com o Mistério neles contido. O Mistério que é dado colher, até onde possível, justamente nessa abordagem ritual que, tomisticamente, em seus efeitos faria resplandecer seu significado ${ }^{93}$. O Mistério constituiu-se nessa dimensão, ao mesmo tempo, enquanto “mistério da palavra" e mistério ritualmente (até onde possível) desvendado.

Mas, na época do debruçar-se de perigosas heterodoxias e de incursões místicas nessa dimensão do sagrado - inclusive aquela do próprio Inácio, fundador da Companhia de Jesus -, a relação, já própria da história do Cristianismo, entre mistério e ministério foi reforçada. E o exemplo mais significativo desse esforço colhe-se, justamente, na codificação doutrinal dos sete rituais sacramentais regulamentados pelo Concílio de Trento. Uma normatização sacramental impunha-se paralelamente à insistência sobre a importância da traditio estabelecida pelos Pais da Igreja. Processo normativo dos rituais sacramentais e mediação da Patrística estabeleceram-se como os nós fundamentais da mediação eclesiástica católica na aproximação do Mistério dos sacra.

Nessa aproximação, o ministério da palavra e o ministério sacramental (ritual) se configuram como as principais traduções dessa sacralidade, necessa-

\footnotetext{
${ }^{92}$ RAFAEL, Vicente L. Contracting Colonialism. Op.cit., p. 91-92.

${ }^{93}$ AMADIO, A. M. "Sacraments of the Church". In: New Catholic Encyclopedia. New York: McGraw-Hill, 1967, vol. 4, p. 808. Citado por Rafael, Contracting Colonialism..., Op.cit., p. 92 .
} 
riamente administrada. Do ponto de vista catequético, essa administração caracterizava-se, enquanto tal, tanto na tradução (lingüística e sacramental) dos catecismos, quanto na normatização (dos gestos, dos momentos e dos significados) dos sacramentos. Todavia, a extensão missionária da universalidade de um crer e de suas mediações sacramentais, junto aos instrumentos lingüísticos que afinava para sua doutrinação, estava longe de (poder) conseguir essa rígida normatização e ortodoxia. Pelo contrário, e necessariamente, o imperativo expansionista missionário acabava abrindo, como no caso americano, um inevitável espaço de negociação, entre perspectivas culturais diferenciadas, que resultava alargar, muitas vezes para além dos limites suspeitados pelos próprios missionários, a estrita rede da normatização doutrinal e a presumida ortodoxia da tradução lingüística e sacramental.

Uma primeira verificação desse fato, como em outras características situações lingüísticas no caso americano, pode ser encontrada na significativa intraduzibilidade do próprio termo "sacramento". Este não parece ter encontrado uma tradução utilizável (pelo menos sem perigo de confusão com as práticas rituais indígenas) em nenhum dos catecismos e em nenhuma língua da nossa documentação: tanto em tupi, como em guarani e em kariri, o termo foi introduzido como tal (com o significante das línguas ocidentais) dentro do texto em vernáculo. Podemos imaginar, portanto, quanto essa introdução terminológica estranha pudesse se apresentar, em princípio, insignificante para os indígenas: e se o processo de significação se construía na doutrina e na prática sacramental, há de se entrever a concreta possibilidade de uma sobreposição de significados, nas duas perspectivas culturais que entraram em relação: nas ritualidades que fundamentavam o encontro, assim como na doutrina não dificilmente desdobrável em sua interpretação ritual.

Eis que, por exemplo, nas introduções catequéticas jesuítas em tupi, a primeira característica através da qual foram definidos os sacramentos é a de 'remédio', 'medicina' (possanga ${ }^{94}$, mosanga ${ }^{95}$ ), com exclusão do Pe. Vincencio

\footnotetext{
${ }^{94}$ Em: Pe. José de ANCHIETA. Doutrina Cristã - Tomo 1: Catecismo Brasílico. Com texto tupi e português. Introdução tradução e notas do CARDOSO, Pe. Armando, S.J. Incluindo o texto fac-similar (tupi) manuscrito classificado como APGSI N. 29 ms. 1730. São Paulo: Loyola, 1992: fólio 27.

${ }^{95}$ Em: Pe. José de ANCHIETA. Diálogo da Fé Diálogo da Fé. Texto tupi e português com introdução histórico-literária e notas do CARDOSO, Pe. Armando, S.J., que inclui os textos fac-similares manuscritos classificados como APGSI N. 29 ms. 1730 e ARSI Opp. NN. 22
} 
Mamiani que optou por defini-lo enquanto "sinal visível da 'graça' (em português no texto kariri) invisível (graça que ele distingue, sempre rigorosamente em português, em 'santificante' e 'auxiliante')". ${ }^{96} \mathrm{O}$ termo vernáculo kiriri para remédio parece também ter sido aquele escolhido pelo franciscano Bernardo de Nantes ${ }^{97}$. Em relação a essa caracterização medicinal do sacramento, nos catecismos tupi não aparece a definição terminológica do pecado: este se entrevê na própria definição de um sacramento-remédio da alma (angá), em Anchieta e Araújo (mas também no texto guarani de Montoya, junto ao conceito de justificação), ou na peculiar resolução da definição de graça em Mamiani. Bernardo de Nantes - significativo: um capuchinho e não um jesuíta - é o único autor que insere (traduz) o termo pecado nessa parte de seu catecismo com o signo lingüístico kariri.

Verificamos, ainda, as dificuldades lingüísticas presentes na 'alma' tupi (angá): mas, tanto essas dificuldades, quanto aquelas que se referem ao termo 'pecado', parecem encontrar, juntas, uma sua forma de superação no ensino doutrinal. Desse ponto de vista, o pecado acaba identificando-se como 'doença' - (correspondente tupi: mara'ar, adoecer), em todos os nossos catecismos tupi (além que naquele guarani de Montoya e naquele kariri de Bernardo de Nantes)

e sua cópia APGSI n. 33 ms. 1731. São Paulo: Loyola, 1988: fólio 7. E, finalmente, em Pe. Antonio de ARAÚJO, S.J. Catecismo na Lingoa Brasilica, no qual se contem a svmma da Doctrina Christã. Com tudo o que pertence ao Myfterios de noffa fancta Fè \& bõs cuftumes. Composto a modo de Dialogos por Padres Doctos, \& bons lingoas da Companhia de IESV. Agora nouamente concertado, ordenado, \& acrefcentado pello Padre Antonio d'Araujo Theologo \& lingoa da mefma Companhia. Com as licenças neceffarias. Em Lisboa por Pedro Crasbeeck, ãno 1618. A cufta dos Padres do Brafil. Texto em reprodução fac-similar da $1^{\text {a }}$ ed., com o título Catecismo na Língua Brasílica. Rio de Janeiro: Pontifícia Universidade Católica, 1952: fólio 79.

${ }^{96}$ MAMIANI, S.J. Catecismo Da Doutrina Christãa Na Lingua Brafilica Da Nação Kiriri. Composto Pelo P. LUIS VINCENCIO MAMIANI, Da Companhia de JESUS, Miffionario da Provincia do Brafil. Lisboa, Na Officina de MIGUEL DESLANDES, Impreffor de Sua Mageftade. Com todas as licenças neceffarias. Anno de 1698. Citado na edição fac-similar, Rio de Janeiro, Imprensa Nacional, 1942. Fólio 110.

${ }^{97}$ Bernardo de NANTES. Katecismo Indico Da Lingva Kariris, Acrescentado de Varias Praticas Doutrinaes, \& Moraes, Adaptadas ao Genio, \& Capacidade dos Indios do Brafil, Pelo Padre Fr. BERNARDO DE NANTES, Capuchinho, Pregador, \& Miffionario Apoftolico; Offerecido ao Muy Alto, e Muy Poderoso Rey de Portugal DOM JOAÕ V, S. N. Que Deos Guarde. Lisboa, Na Officina de Valentim da Costa Deslandes, Impreffor de Sua Mageftade. M.DCCIX. Com todas as licenças neceffarias. Que citaremos na edição fac-similar publicada por Julio Platzmann, Leipzig, B. G. Teubner, 1896, p. 70. 
- da 'alma', desse "duplo corporal” (?) tão difícil de traduzir lingüisticamente sem correr o risco de recriar, em sua ressonância perante o conceito de pessoa indígena, um inevitável hibridismo cultural.

Em relação à especificidade dos sacramentos, talvez possamos entrever, de forma mais emblemática e significativa, um processo que se desprendeu, em princípio, a partir de inevitáveis equívocos e mal-entendidos que foram sendo ajustados, na medida em que foi se determinando um alargamento dos instrumentos conceituais e lingüísticos (construídos ex novo ou transformados), para dar conta da inédita situação de catequese. O momento ritual (sacramental) da prática catequética representa, portanto, segundo tudo quanto entrevemos e apontamos, o momento da verificação dos resultados dessa comunicação, ao mesmo tempo em que se constitui enquanto um reajuste da própria prática sacramental (de seu prestar-se a equívocos) e de sua tradução (ameaçadora) para dentro do mundo cultural indígena. A verificação do momento ritual aponta, de fato, para a fluidez, inevitável, das barreiras lingüísticas e culturais, em princípio dadas por adquiridas. Segundo a nossa perspectiva de análise, nessa peculiar dimensão do encontro cultural, antes de uma administração dos sacramentos por parte dos missionários, verifica-se uma recíproca administração nos rituais sacramentais dos diferentes paradigmas culturais (indígenas e missionários). A administração dos sacramentos cristãos acabava por se estruturar como o espaço privilegiado de um hibridismo cultural que se encontrava na necessidade de reescrever essa relação (ritual) com o sagrado, segundo uma nova estrutura, muitas vezes compartilhada - consciente ou inconscientemente - por missionários e indígenas. 